\title{
11. PACIFIC COAST COCCOLITH STRATIGRAPHY BETWEEN POINT CONCEPTION AND CABO CORRIENTES, DEEP SEA DRILLING PROJECT LEG 631
}

\author{
David Bukry, United States Geological Survey, Scripps Institution of Oceanography, La Jolla, California
}

\begin{abstract}
DSDP Leg 63 recovered Neogene coccoliths from south of Point Conception, California (Site 467), to north of Cabo Corrientes, Mexico (Site 473), as part of a traverse exploring the sedimentary record of the California Current along the Pacific Coast. A combination of temperate and tropical zonations were used to date Leg 63 coccolith assemblages because of intergradations of warm and cool species along the transect. Variations in the abundance and the presence and absence of Discoaster species are useful in recognizing warm-cool intergradations. New taxa described in this report include Discoaster okadai n. sp., D. sammiguelensis n. sp., Helicosphaera californiana n. sp., H. crouchii n. sp., $H$. gertae n. sp., and $H$. vedderi n. sp.
\end{abstract}

\section{INTRODUCTION}

Leg 63 of the Deep Sea Drilling Project recovered 398 cores at seven drilling sites, 467 through 473 (Fig. 1, A). These sites all lie south of DSDP Site 173 (Fig. 1, B), which is a standard reference for middle-latitude biostratigraphy along the Pacific Coast. Light-microscope techniques were used to study a set of 1100 coccolith smear slides. At most sites coccoliths provided the most continuous biostratigraphic record for correlation, however, gaps are indicated in the summary of coccolith zonal sequences (Figs. 2 and 3). Different sections in this chapter discuss zonation, site summaries, variation of assemblages along the traverse of sites, systematic paleontology, and species cited.

\section{ZONATION}

Low-latitude coccolith zonation (Bukry, 1971a, 1973a, 1975) can be applied to the lower middle Miocene at all of the Leg 63 sites. A significant change in assemblages at northern Sites 467 to 469 occurred in the middle Miocene Discoaster exilis Zone (Crouch and Bukry, 1979); low-diversity temperate assemblages became established and low-latitude guide taxon became sparse and sporadic. Temperate zones developed from Leg 18 (Bukry, 1973b), which span broader time intervals than do low-latitude zones, are used for the upper middle Miocene to lower Pliocene for Sites 467 and 468, with a minor change. The modification is that the earliest $D$. mendomobensis occurs in the $D$. neorectus Subzone correlative (in Leg 63 sites) instead of at the upper boundary of the $D$. neorectus Zone. The zone and subzone codes $(\mathrm{CN} 12 \mathrm{a} . .$.$) are from Okada and Bukry$ (1980) (Fig. 4).

In the lower Pliocene of Holes 467, 468, 468A, and 469 , a new local or limited middle-latitude subzone is recognized. The new Amaurolithus delicatus Subzone CN10d is bounded by the first consistent Discoaster

\footnotetext{
${ }^{1}$ Initial Reports of the Deep Sea Drilling Project, Volume 63.
}

asymmetricus Gartner at the base and by the last Amaurolithus spp. at the top. It is assigned to the top of the Amaurolithus tricorniculatus Zone CN10, above the Ceratolithus rugosus Subzone CN10c. This unit is not part of the regular low-latitude zonation, because the Amaurolithus extinction typically precedes the first consistent $D$. asymmetricus populations; however, this unit has been identified previously as a Discoaster asymmetricus Zone by Gartner (1969) and Martini (1971). The sporadic occurrence of $D$. asymmetricus in the upper Miocene (Bukry, 1973a; Shafik, 1975) can cause problems with this subzone. The occurrence of this unit in tropical areas is questionable, because my slides from DSDP Hole 62.1 , Core $10\left(01^{\circ} 52.2^{\prime} \mathrm{N}\right)$, identified as $D$. asymmetricus Zone (Martini, 1971), show Ceratolithus rugosus Bukry and Bramlette and D. asymmetricus, but no Amaurolithus, which should signify the low-latitude Reticulofenestra pseudoumbilica Zone CN11a and b (compare Martini, 1971). The Leg 63 occurrences of the overlap between Amaurolithus and D. asymmetricus are in single samples or very short intervals of 1 or 1.5 meters at California Continental Borderland Sites 467 to 469 . The brevity of this unit, which is also indicated by Gartner (1969) for Atlantic cores, may be a function of the sporadic occurrence of D. asymmetricus in the lower lower Pliocene and local variations in gradually increasing productivity near the extinction of Amaurolithus. This could account for the brevity or apparent nonoverlapping relation between these taxa in various regions. Detailed study of subsection intervals through the lower Pliocene in additional tropical and temperate cores should resolve this subzone correlation.

The upper Miocene zonal boundary between the middle-latitude Discoaster mendomobensis Zone and $D$. variabilis Zone, when first described, was correlated with the boundary between the low-latitude $D$. quinqueramus Zone and D. neohamatus Zone (Bukry, 1973b). Studies of borderland dart cores and DSDP Site 469 , Core 14, however, show that specimens of Discoaster mendomobensis Wise may occur earlier, in upper $D$. neohamatus Zone assemblages identified by the 


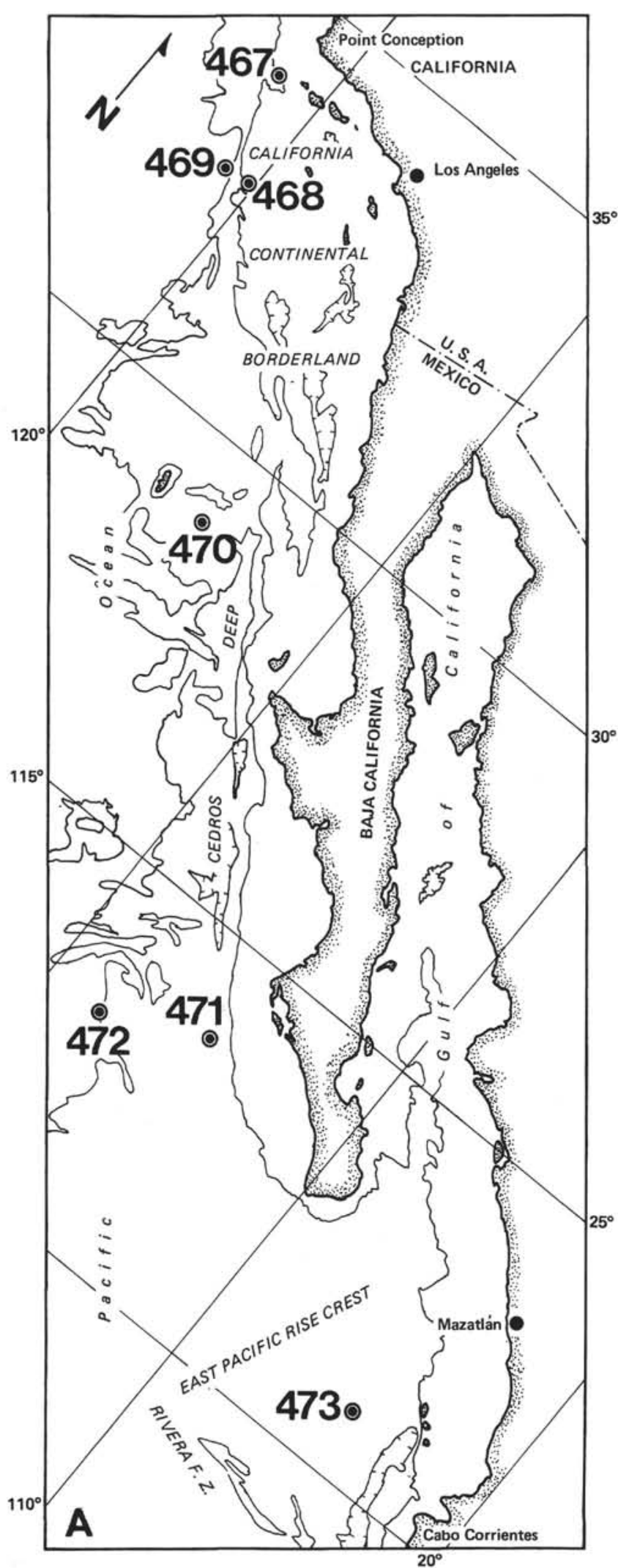

Figure 1. A. Location of DSDP Leg 63 sites along the Pacific Coast from Point Conception to Cabo Corrientes. (The Experimental Mohole Site is $8 \mathrm{~km}$ north of DSDP 470.) B. Locations of Site 173 and Leg 63 sites used for coccolith ratios along the Pacific Coast traverse.

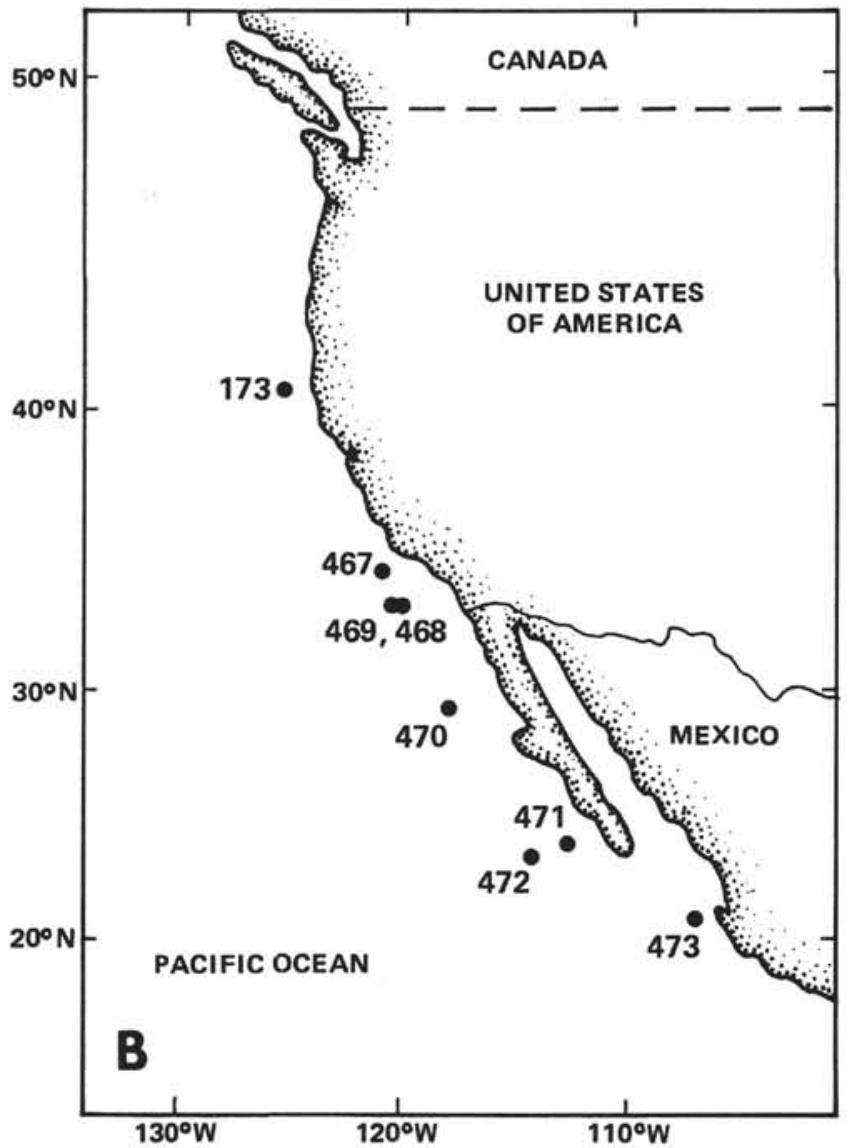

Figure 1. (Continued).

occurrence of $D$. bellus Bukry and Percival, D. loeblichii Bukry, and Minylitha convallis Bukry, without $D$. berggrenii Bukry, D. quinqueramus Gartner, or $D$. surculus Martini and Bramlette. Therefore, the bottom of the $D$. mendomobensis Zone appears to be slightly below the top of the $D$. neohamatus Zone in the borderland where species characterizing both of these latitudinal zones occur together.

The low-latitude zonation for the upper Pliocene and Quaternary is generally recognizable through the Leg 63 area. Site 467 presents the most difficulty, with etched assemblages containing reworked specimens but few discoasters. The brief Discoaster pentaradiatus Subzone CN12c occurs only at Site 470 . Quaternary assemblages contain fairly representative numbers of Ceratolithus, Emiliania, and Gephyrocapsa, but dilution by terrigenous or opal biogenic sediment hinders zonal assignments.

\section{SITE SUMMARIES}

Site 467

$\left(33^{\circ} 50.97^{\prime} \mathrm{N}, 120^{\circ} 45.47^{\prime} \mathrm{W}\right.$, depth $\left.2128 \mathrm{~m}\right)$

The Miocene to Quaternary coccoliths at Site 467 in the San Miguel Gap constitute much of the micropaleontologic record of the California Current in the outer California Continental Borderland. Coccoliths occur in most of the 110 cores recovered. Middle Miocene to 


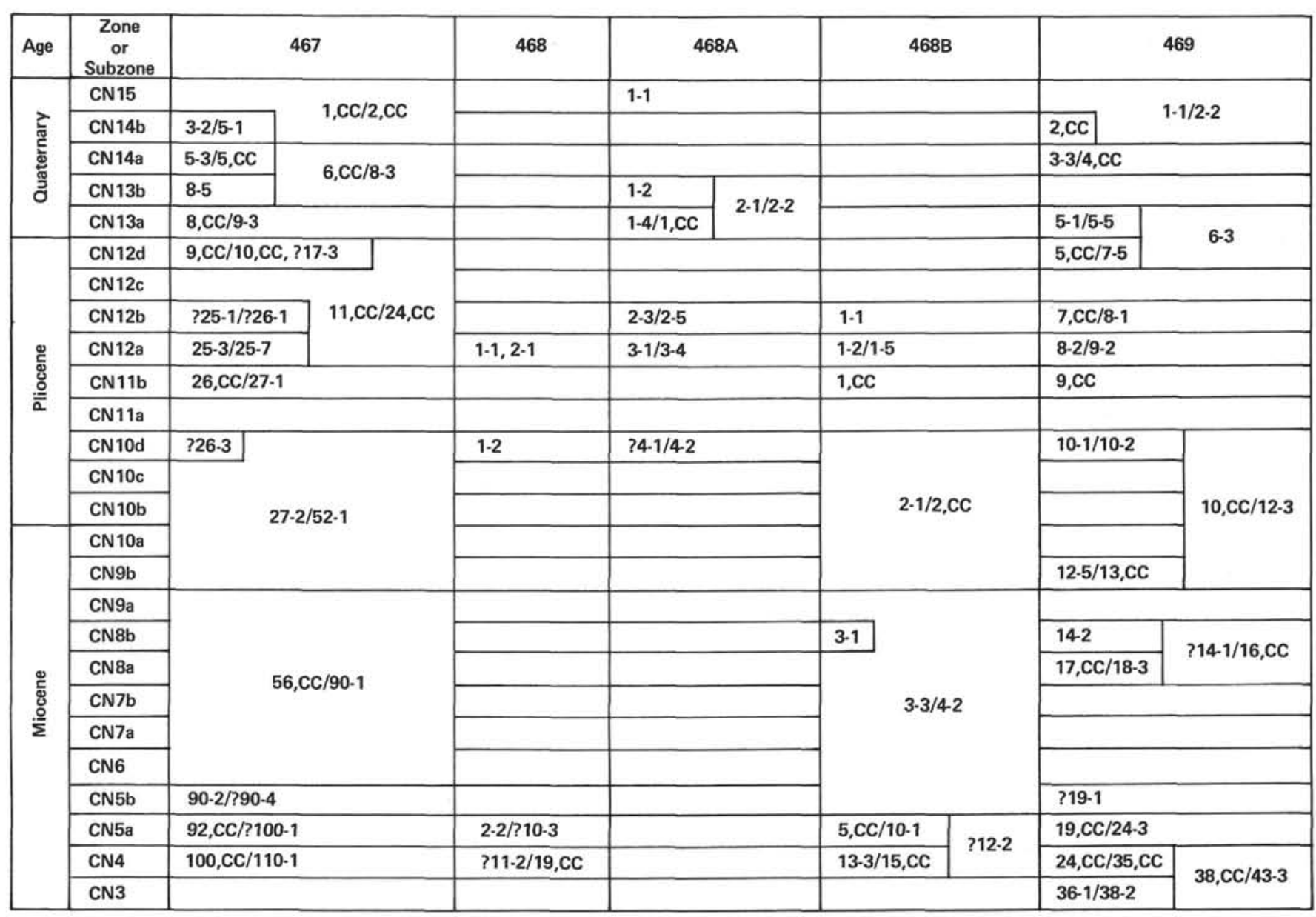

Figure 2. Coccolith zonation of core samples from northern Sites 467 to 469 of DSDP Pacific Coast Leg 63. (The numbers assigned to zonal intervals are core and section numbers of samples examined. Where a zone or subzone is represented in samples from two or more core sections, the highest and lowest are given. $\mathrm{CC}=$ core-catcher sample from the bottom of the core.)

lowest Pliocene coccoliths are generally few to common and are moderately to poorly preserved. Dissolution and fragmentation of both placolith and asterolith specimens are typical in Cores 37 to 110 . Coccoliths are abundant and moderately well preserved in Quaternary and Pliocene Cores 1 to 36 . Reworked coccoliths from the Eocene occur sparsely through Quaternary Cores 1 to 9 and in Cores 32 and 42 but are essentially absent in Miocene Cores 47 to 110 .

Biostratigraphically, few of the 24 low-latitude coccolith units (zones and subzones) for the middle Miocene to Quaternary could be specifically identified because of the paucity of low-latitude marker species in the low-diversity (2-10 species) assemblages. The most frequently recurring species are relatively cosmopolitan species such as Amaurolithus primus (Bukry and Percival), Calcidiscus leptoporus (Murray and Blackman), C. macintyrei (Bukry and Bramlette), Coccolithus pelagicus (Wallich), Crenalithus taganus (Fonseca) s. ampl., Discoaster brouweri Tan s. ampl., D. intercalaris Bukry, D. variabilis Martini and Bramlette, and Reticulofenestra pseudoumbilica (Gartner) s. ampl. The coolwater Discoaster variabilis Zone (Milow, 1970; Bukry, 1973b) had to be used for most of the upper Miocene and part of the middle Miocene (Cores 56-90). The Amaurolithus tricorniculatus Zone (Bukry, 1973a) that includes the Miocene/Pliocene boundary could not be divided effectively into subzones because of the scarcity or absence of Ceratolithus acutus Gartner and Bukry, C. rugosus Bukry and Bramlette, and Triquetrorhabdulus rugosus Bramlette and Wilcoxon. The Miocene/ Pliocene boundary is provisionally drawn between Cores 45 and 47, because the silicoflagellate Dictyocha aspera clinata Bukry is present in Core 47.

The oldest zone identified at Site 467 is the Sphenolithus heteromorphus Zone, which is part of the early middle Miocene (approximately 14.0-15.5 Ma). R. Z. Poore (personal communication, 1978) has identified this zone in the type Luisian Stage onshore in California. The zonal assemblages at Site 467 include sparse Sphenolithus heteromorphus Deflandre, Helicosphaera carteri (Wallich), and Calcidiscus macintyrei (Bukry and Bramlette); few Coccolithus miopelagicus Bukry, Discoaster deflandrei Bramlette and Riedel, D. exilis Martini and Bramlette, and D. variabilis Martini and Bramlette; and common Cyclicargolithus floridanus (Roth and Hay). Assemblages of the upper Coccolithus miopelagicus Subzone are characterized by $C$. mio- 


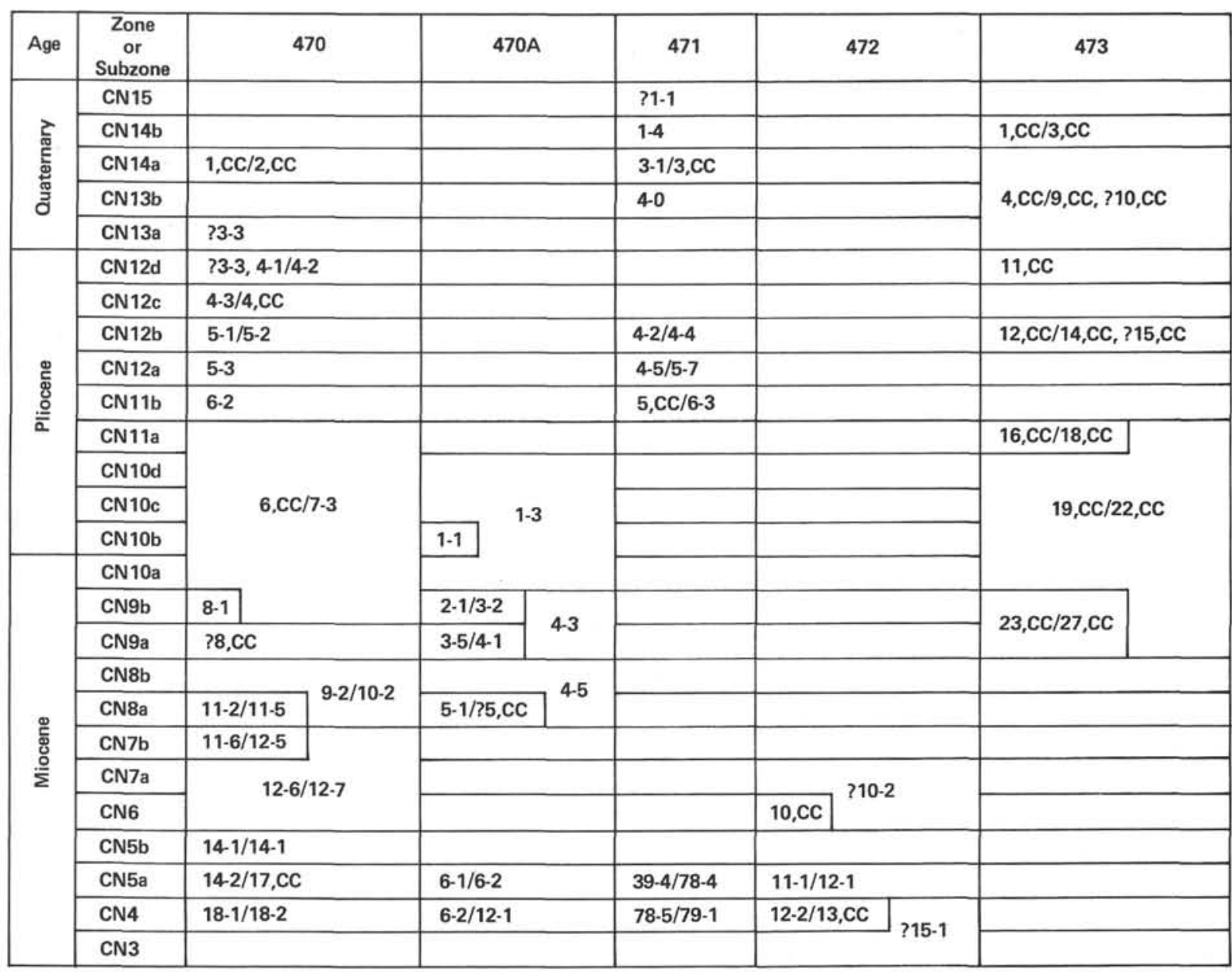

Figure 3. Coccolith zonation of core samples from southern Sites 467 to 473 of DSDP Pacific Coast Leg 63. (The numbers assigned to zonal intervals are core and section numbers of samples examined. Where a zone or subzone is represented in samples from two or more core sections, the highest and lowest are given. $\mathrm{CC}=$ core-catcher sample from the bottom of the core.)

pelagicus, Crenalithus taganus (Fonseca) s. ampl., Cyclicargolithus floridanus, D. exilis, and Reticulofenestra pseudoumbilica (Gartner). In the lower part of the subzone, $R$. pseudoumbilica is less common and Sphenolithus neoabies is more common, suggesting some decrease in paleotemperature upward through the interval. However, the more common occurrence of discoasters in the Discoaster kugleri Subzone, just below a long sequence of cool-temperature assemblages, indicates that the environment was rather warm.

Above, in Cores 56 to 90, cooler, temperate, low-diversity coccolith assemblages, dominated by species of Reticulofenestra and $D$, variabilis, are present. The long Discoaster variabilis Zone interval can be divided into lower and upper parts by the appearances of Discoaster brouweri Tan s. ampl. in the lower part and Minylitha convallis Bukry in the upper part, which corresponds with the low-latitude upper Miocene Discoaster neohamatus Zone. Warm-water Discoaster neohamatus Bukry and Bramlette is absent, emphasizing the nontropical character of the assemblages. However, no specimens of cool-water Discoaster mendomobensis
Wise were detected; this species flourished to the north at DSDP Site 173 at the northern end of the California Current for a short interval at the top of the $D$. variabilis Zone and has rare occurrences in the California Continental Borderland (D. Bukry, unpublished data, 1978).

Sporadic occurrences of guide species Amaurolithus delicatus Gartner and Bukry, A. primus (Bukry and Percival), and Discoaster quinqueramus Gartner in the upper Miocene to lower Pliocene interval of Cores 27 to 55 make zonal assignments of individual samples difficult. Cores 27 to 55 are assigned to an undifferentiated A. primus Subzone or A. tricorniculatus Zone because of the absence of warm-water ceratolith guide species.

The overlap of Discoaster tamalis Kamptner and $D$. asymmetricus Gartner in Section 467-26-1 indicates the Discoaster tamalis Subzone or D. asymmetricus Subzone. Therefore this level correlates to the type Repettian Stage onshore (R. Arnal and D. Bukry, unpublished data, 1978).

Division of the upper Pliocene into subzones is doubtful at Site 467 because of the scarcity or absence 


\begin{tabular}{|c|c|c|c|c|c|}
\hline AGE & \multicolumn{2}{|r|}{ ZONE } & & SUBZONE & $\begin{array}{l}\text { Martini } \\
\text { (1971) } \\
\text { Zone }\end{array}$ \\
\hline \multirow{5}{*}{ 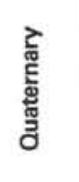 } & CN15 & \multicolumn{3}{|l|}{ Emiliania huxleyi } & NN21 \\
\hline & \multirow{2}{*}{ CN14 } & \multirow{2}{*}{$\begin{array}{c}\text { Gephyrocapsa } \\
\text { oceanica }\end{array}$} & CN14b & Ceratolithus cristatus & NN20 \\
\hline & & & CN14a & Emiliania ovata & \multirow{3}{*}{ NN19 } \\
\hline & \multirow{2}{*}{ CN13 } & \multirow{2}{*}{$\begin{array}{c}\text { Crenalithus } \\
\text { doronicoides }\end{array}$} & CN13b & Gephyrocapsa caribbeanica & \\
\hline & & & CN13a & Emiliania annula & \\
\hline \multirow{8}{*}{ 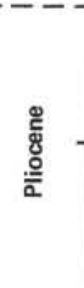 } & \multirow{4}{*}{ CN12 } & \multirow{4}{*}{$\begin{array}{l}\text { Discoaster } \\
\text { brouweri }\end{array}$} & CN12d & Calcidiscus macintyrei & NN18 \\
\hline & & & CN12c & Discoaster pentaradiatus & NN17 \\
\hline & & & CN12b & Discoaster surculus & \multirow{2}{*}{ NN16 } \\
\hline & & & CN12a & Discoaster tamalis & \\
\hline & \multirow{2}{*}{ CN11 } & \multirow{2}{*}{$\begin{array}{l}\text { Reticulofenestra } \\
\text { pseudoumbilica }\end{array}$} & CN11b & Discoaster asymmetricus & \multirow{2}{*}{ NN15 } \\
\hline & & & CN11a & Sphenolithus neoabies & \\
\hline & \multirow{4}{*}{ CN10 } & & CN10d & Amaurolithus delicatus & NN14 \\
\hline & & Amaurolithus & CN10c & Ceratolithus rugosus & NN13 \\
\hline & & tricorniculatus & CN10b & Ceratolithus acutus & NN12 \\
\hline & & & CN10a & Triquetrorhabdulus rugosus & INIV iL \\
\hline & CNG & Discoaster & CN9b & Amaurolithus primus & NN11 \\
\hline & Civg & quinqueramus & CN9a & Discoaster berggrenii & NINIT \\
\hline & & Discoaster & CN8b & Discoaster neorectus & \\
\hline & CIN8 & neohamatus & CN8a & Discoaster bellus & NINTO \\
\hline & CN7 & Discoaster & CN7b & Catinaster calyculus & NN9 \\
\hline Е & CIN/ & hamatus & CN7a & Helicosphaera carteri & NIN9 \\
\hline$\stackrel{8}{0}$ & CN6 & Catinaster coalitus & & & NN8 \\
\hline $\bar{\Sigma}$ & CN5 & Discoaster & CN5b & Discoaster kugleri & NN7 \\
\hline & & exilis & CN5a & Coccolithus miopelagicus & NN6 \\
\hline & CN4 & Sphenolithus heteromorphus & & & \\
\hline & CN3 & Helicosphaera ampliaperta & & & NINP/NIN5 \\
\hline & CN2 & Sphenolithus belemnos & & & NINZ/NINb \\
\hline & & & CN1c & Discoaster druggii & \\
\hline & CN1 & Iriquetroornabaulus & CN1b & Discoaster deflandrei & \\
\hline & & & CN1a & Cyclicargolithus abisectus & NP25/NN1 \\
\hline & CP19 & Sphenolithus & CP19b & Dictyococcites bisectus & \\
\hline & CPIS & ciperoensis & CP19a & Cyclicargolithus floridanus & NP24 \\
\hline ఫ్ & CP18 & Sphenolithus distentus & & & NP23 \\
\hline$\stackrel{9}{g}$ & CP17 & Sphenolithus predistentus & & & INP 20 \\
\hline$\overline{0}$ & & & CP16c & Reticulofenestra hillae & NP22 \\
\hline & CP16 & $\begin{array}{l}\text { Helicosphaera } \\
\text { reticulata }\end{array}$ & CP16b & Coccolithus formosus & NP21 \\
\hline & & & CP16a & Coccolithus subdistichus & NAPI \\
\hline & CP15 & Discoaster & CP15b & Isthmolithus recurvus & NP19/NP20 \\
\hline & CP15 & barbadiensis & CP15a & Chiasmolithus oamaruensis & NP18 \\
\hline & CP14 & Reticulofenestra & CP14b & Discoaster saipanensis & NP17 \\
\hline & CP14 & umbilica & CP14a & Discoaster bifax & \\
\hline & & & CP13c & Coccolithus staurion & NP15/NP16 \\
\hline & CP13 & Nannotetrina & CP13b & Chiasmolithus gigas & 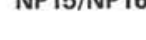 \\
\hline 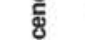 & & & CP13a & Discoaster strictus & \\
\hline Шัّ & & Discoaster & CP12b & Rhabdosphaera inflata & \\
\hline & CP12 & sublodoensis & CP12a & Discoasteroides kuepperi & NP14 \\
\hline & CP11 & Discoaster lodoensis & & & NP12/NP13 \\
\hline & CP10 & Tribrachiatus orthostylus & & & TNF TLINTH IS \\
\hline & CP9 & Discoaster & $\mathrm{CP9b}$ & Discoaster binodosus & NP11 \\
\hline & & diastypus & $\mathrm{CP9a}$ & Tribrachiatus contortus & NP10 \\
\hline & & & $\mathrm{CP} 8 \mathrm{~b}$ & Campylosphaera eodela & NPG \\
\hline & CP8 & multiradiatus & CP8a & Chiasmolithus bidens & NPY \\
\hline & CP7 & Discoaster nobilis & & & \\
\hline & CP6 & Discoaster mohleri & & & NP7/NP8 \\
\hline 鹿 & CP5 & Heliolithus kleinpellii & & & NP6 \\
\hline . & $\mathrm{CP} 4$ & Fasciculithus tympaniformis & & & NP5 \\
\hline$\frac{0}{0}$ & $\mathrm{CP3}$ & Ellipsolithus macellus & & & NP4 \\
\hline & CP2 & Chiasmolithus danicus & & & NP3 \\
\hline & CP1 & & CP1b & Cruciplacolithus tenuis & NP2 \\
\hline & $\mathrm{CP1}$ & sigmoides & CP1a & Cruciplacolithus primus & NP1 \\
\hline
\end{tabular}

Figure 4. Coccolith zonation and supplementary codes used for this chapter (Bukry, 1973a, 1975; Okada and Bukry, 1980). 
of discoasters, especially $D$. pentaradiatus and $D$. surculus Martini and Bramlette. Both taxa, however, occur in the lower Pliocene at Site 467.

The highest occurrence of Discoaster brouweri Tan and common Calcidiscus macintyrei (Bukry and Bramlette) in Core 9 is used to correlate the top of the Pliocene. Sample 8,CC contains the last $C$. macintyre $i$ without discoasters and is assigned to the lower Pleistocene Emiliania annula Subzone. A mixed-temperate environmental aspect of the Quaternary assemblages is shown by the persistence of cool-water Coccolithus pelagicus (Wallich) and warm-water Ceratolithus cristatus Kamptner through Cores 1 to 5. Cold-water C. pliopelagicus Wise is sparser at Site 467 than at Site 173, and $C$. pelagicus is missing from coeval DSDP Leg 54 sites near the southern end of the California Current. Therefore the Quaternary coccolith assemblages from the Site 467 region of the California Current suggest a gradational change in assemblages southward along the current.

The coccolith record at Site 467 shows climatic changes from warm in early middle Miocene (Coccolithus miopelagicus Bukry, emended, Wise; Cyclicargolithus floridanus [Roth and Hay]; Discoaster deflandrei Bramlette and Riedel; D. exilis Martini and Bramlette; Sphenolithus heteromorphus Deflandre; $S$. neoabies Bukry and Bramlette), to cool in late middle Miocene to early Pliocene (low diversity with Discoaster variabilis Martini and Bramlette and Reticulofenestra pseudoumbilica [Gartner] and essentially no Ceratolithus, Discoaster loeblichii Bukry, D. pentaradiatus Tan, D. quinqueramus Gartner, D. surculus Martini and Bramlette, or Triquetrorhabdulus), to warm in middle Pliocene (Ceratolithus, Discoaster asymmetricus Gartner, D. pentaradiatus Tan, and D. tamalis Kamptner), to mixed cool and warm in the Pleistocene (by fluctuations in Ceratolithus, Coccolithus, and Gephyrocapsa). The lower 55 cores (representing most of the Miocene) lack diatoms, radiolarians, and even planktonic foraminifers, suggesting deposition from a sluggish or distal portion of any eastern boundary current. Changes in submarine topography or current circulation patterns in the late Miocene apparently brought the San Miguel Gap area under the active part of the California Current, because the low-fertility coccolith claystones and siltstones pass upward into diatom-, silicoflagellate-, radiolarian-, ebridian-, and dinoflagellate-bearing biogenic ooze. This change indicates the higher fertility of upwelled waters, in contrast to the deeper cores where coccolith predominance indicates low to moderate fertility.

\section{Site 468 \\ $\left(32^{\circ} 37.03^{\prime} \mathrm{N}, 120^{\circ} 07.07^{\prime} \mathrm{W}\right.$, depth $\left.1849 \mathrm{~m}\right)$ Holes 468A and $B$ \\ $\left(32^{\circ} 37.41^{\prime} \mathrm{N}, 120^{\circ} 06.55^{\prime} \mathrm{W}\right.$, depth $\left.1737 \mathrm{~m}\right)$}

Warm-water coccoliths characterize the short Pliocene and Quaternary interval at Holes 468, 468A, and 468B. Most of the cores from Site 468 are barren or contain middle Miocene Discoaster exilis Zone or Sphenolithus heteromorphus Zone coccoliths. The upper Mio- cene occurs in only a few cores, suggesting one or more major hiatuses. The upper Miocene to lower Pliocene at Hole 468A, Core 4, is notable for the presence of a coolwater facies with discoasters dominated by Discoaster variabilis Martini and Bramlette and for a warm-water facies with discoasters dominated by $D$. brouweri Tan, $D$. pentaradiatus Tan, and $D$. surculus Martini and Bramlette. Site 468 assemblages appear warmer than those of Site 467 on the basis of Ceratolithus in the Pliocene and more common Discoaster, Discolithina, $\mathrm{He}$ licosphaera, and Sphenolithus in the middle Miocene. Preservation is generally moderate throughout Site 468; solution is less severe than at Site 467 . Overgrowth occurs only in the middle Miocene and is minor.

Many Leg 63 Miocene discoasters have exceptionally large central stems, the most prominent being Discoaster sanmiguelensis n. sp., which is common in Sample $468-7-3,50-51 \mathrm{~cm}(55 \mathrm{~m})$. Warm-water $D$. signus Bukry occurs sparsely in the thick Coccolithus miopelagicus Subzone of Site 468, being noteworthy in Sample 468-7-3, 50-51 cm, where warm-water Sphenolithus is abundant.

\section{Site 469 \\ $\left(32^{\circ} 37.00^{\prime} \mathrm{N}, 120^{\circ} 32.90^{\prime} \mathrm{W}\right.$, depth $\left.3790 \mathrm{~m}\right)$}

Lower Miocene to upper Quaternary coccolith assemblages are typically abundant, diverse, and moderately well preserved at Site 469 . Lower upper Miocene warm-water discoasters-Discoaster bellus Bukry and Percival, D. loeblichii Bukry, D. neohamatus Bukry and Bramlette, and D. pentaradiatus Tan-in Cores 13 to 18 distinguish the Site 469 assemblages from coolerwater, less diverse assemblages of the upper Miocene at Site 467. Although the upper Miocene record is less complete at nearby Site 468 , the correlative assemblages are similar to those at Site 469 for the upper Miocene, suggesting a similar oceanographic environment.

Reworked Eocene or Oligocene coccoliths give some evidence for the amount and duration of erosion in the vicinity of Site 469 . Displaced Eocene and Oligocene species are sparse in middle and lower Miocene Cores 27, 32 to 39 , and 43, common in middle Miocene Cores 28 to 31 , and absent in Quaternary to middle Miocene Cores 1 to 26. This distribution is in contrast to Site 467, where reworked Eocene and Oligocene specimens are recorded only from the Pliocene and Quaternary.

The oldest coccoliths from Site 469 are sparse, moderately preserved specimens from a baked, reddish, metalliferous sediment intercalated with basalt in Core 45. A smear slide of Sample 469-45-1, 90-93 cm contains Helicosphaera carteri, which indicates deposition in the early Miocene or later. The oldest sediment above basalt, in Core 43, probably belongs to the lower part of the Helicosphaera ampliaperta Zone, considered to be of late early Miocene age (Bukry, 1979). An overlap between Sphenolithus heteromorphus Deflandre and Triquetrorhabdulus milowii Bukry suggests the lower part of the $H$. ampliaperta Zone (Bukry, 1971a) comprises Core 43. Helicosphaera ampliaperta Bramlette and Wil- 
coxon ranges from Sections 469-36-1 to 469-38-2; deeper samples contain $S$. heteromorphus without $H$. ampliaperta.

A diabase sill cored in Cores 40 to $42(368.5-387 \mathrm{~m})$ is within the $H$. ampliaperta Zone (approximately 15.5 $17.5 \mathrm{~m} . \mathrm{y}$. old). S. heteromorphus Zone (approximately 14-15.5 m.y. old) assemblages from Core 24 to Core 35 , providing evidence for a high rate of sedimentation for the middle Miocene. Four cores from the interval, however, contain sandy sediments with reworked Eocene or Oligocene coccoliths, such as Chiasmolithus grandis (Bramlette and Riedel), Dictyococcites bisectus (Hay, Mohler, and Wade), Discoaster barbadiensis Tan, and Reticulofenestra umbilica (Levin).

The middle Miocene Discoaster exilis Zone of Core 19 is separated from the upper Miocene Discoaster neohamatus Zone in Core 17 by a probable unconformity. After encountering a "sand" during the cutting of Core 18 , there was difficulty in retrieving the core barrel. It is apparent from the mixed colors and late Miocene ages of the pea-sized drill cuttings constituting Core 18 that flow-in occurred. Discoaster sp. cf. D. kugleri Martini and Bramlette occurs in Core 19 in the upper part of the D. exilis Zone, which suggests correlation to Core 90 at Site 467.

Discoaster neohamatus Bukry and Bramlette s. str. is present in Core 15 and represents the northernmost record of this tropical and subtropical species in the eastern Pacific. The D. neohamatus Zone, also identified by the use of $D$. bellus Bukry and Percival, $D$. brouweri Tan, D. loeblichii Bukry, D. prepentaradiatus Bukry and Percival, and Minylitha convallis Bukry, ranges from Core 14 to Core 17 (121.5-159.5 m). Silicoflagellates are especially common and diverse in this interval, suggesting fertile and variable oceanographic conditions. Minylitha convallis appears relatively late at Site 469, within the Discoaster neohamatus Zone in Section 469-15-1, just below the first Discoaster loeblichii Bukry in Section 469-14-2. The Section 469-14-2 assemblage also contains the Pacific Coast middle-latitude species Discoaster mendomobensis Wise. On the basis of its occurrence in Section 469-14-2 and in another borderland dart core, $D$. mendomobensis appears to range slightly below $D$. quinqueramus, creating a possible offset between the Discoaster variabilis Zone/Discoaster mendomobensis Zone boundary of middle latitudes and the Discoaster neohamatus Zone/Discoaster quinqueramus Zone boundary of low latitudes (Bukry, 1973b) along the Pacific Coast.

The paucity of Ceratolithus, Discoaster quinqueramus Gartner, and Triquetrorhabdulus rugosus Bramlette and Wilcoxon precludes precise placement of the Miocene/Pliocene boundary. Amaurolithus primus (Bukry and Percival) ranges through the interval in Cores 10 and 13 and indicates the Amaurolithus primus Subzone or Amaurolithus tricorniculatus Zone. A brief mid-latitude overlap between Amaurolithus delicatus Gartner and Bukry and Discoaster asymmetricus Gartner occurs in Core 10 and is recorded as the local Amaurolithus delicatus Subzone (CN10d). Other taxa present in the Core include Ceratolithus sp. aff. $C$. acutus Gartner and Bukry, C. rugosus Bukry and Bram- lette, and A. primus (Bukry and Percival), which helps to confirm a lower Pliocene correlation.

The upper nine cores contain a seemingly incomplete upper Pliocene and Quaternary coccolith succession, although the recovered sediment commonly is disturbed by drilling operations. Discoaster and Gephyrocapsa are sufficiently diverse to permit recognition of low-latitude subzones. However, cool-water Coccolithus pelagicus (Wallich) is present throughout the Quaternary and Pliocene, and warm-water Ceratolithus occurs only at the top of the interval, in the upper Emiliania ovata Subzone of Core 3 and in Pliocene Cores 6 and 9. This contrasts with the prominent occurrences of these taxa at the southern end of the California Current in the coring area of DSDP Leg 54 (Bukry, 1980).

\section{Site 470}

$\left(28^{\circ} 54.46^{\prime} \mathrm{N}, 117^{\circ} 31.11^{\prime} \mathrm{W}\right.$, depth $\left.3549 \mathrm{~m}\right)$

Lower middle Miocene to Quaternary coccoliths are abundant and moderately well preserved in 25 sediment cores above basalt at Holes 470 and $470 \mathrm{~A}$, east of Guadalupe Island. A limestone within the basalt section (Hole 470A, Core 12) contains common but poorly preserved coccoliths of the lower middle Miocene Sphenolithus heteromorphus Zone (14-15.5 m.y. old). The same zone is present directly above basalt.

The deepest coccolith assemblages above basalt at both holes belong to the Sphenolithus heteromorphus Zone. At Hole 470A the boundary with the overlying Coccolithus miopelagicus Subzone (approximately 14 m.y.) is within Core 6. The sediment in lower Core 6 and in Core 7 contains dolomite rhombs, which are most abundant just above basalt (all coccoliths are missing due to diagenesis) and diminish in size and number upward. Thus within 4.4 meters above basalt the sediment of Sample $470 \mathrm{~A}-6-1,1 \mathrm{~cm}(161.5 \mathrm{~m})$ is a nearly pure coccolith ooze with no clumped coccoliths or rhombs.

The sequence of coccolith zones at Holes 470 and $470 \mathrm{~A}$ corresponds closely with the ranges and zones reported from the nearby Experimental Mohole (EM) drillsite (Martini and Bramlette, 1963; Martini, 1971; not Martini, fide Schrader, 1974, who erroneously references Martini, 1971, who never recognized NN5 or NN11 in EM samples and reported NN7 and NN10 only from single samples). Correlation of coccolith zones from the EM site (Martini, 1971) and Site 470 is illustrated in Figure 5. The close correspondence in the depth reported for key coccolith events by Martini and Bramlette (1963) and by this study is shown in the following coccolith correlations:

\begin{tabular}{lccccc}
\hline \multicolumn{1}{c}{ Coccolith Event } & \multicolumn{2}{c}{ EM-8 } & \multicolumn{2}{c}{ DSDP 470 } \\
\hline & Core & $\begin{array}{c}\text { Depth } \\
(\mathrm{m})\end{array}$ & Core & $\begin{array}{c}\text { Depth } \\
(\mathrm{m})\end{array}$ \\
\hline $\begin{array}{l}\text { Highest } \\
\text { Discoaster hamatus } \\
\text { Lowest } \\
\quad \text { Catinaster calyculus }\end{array}$ & 11 & $95-105$ & 11 & $95-105$ \\
$\begin{array}{c}\text { Lowest } \\
\text { Discoaster kugleri }\end{array}$ & 13 & $113-122$ & 12 & $105-114$ \\
\hline & $122-131$ & 14 & $123.5-133.0$ \\
\hline
\end{tabular}




\begin{tabular}{|c|c|c|c|c|}
\hline Age & Zone or Subzone & EM & 470 & $470 A$ \\
\hline \multirow{2}{*}{ 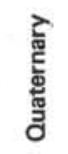 } & E. ovata & \multirow{2}{*}{ WASHED } & $1, \mathrm{CC}$ to $2, \mathrm{CC}$ & \multirow{7}{*}{ WASHED } \\
\hline & E. annula & & 73-3 & \\
\hline \multirow{5}{*}{ 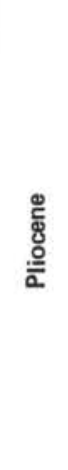 } & C. macintyrei & \multirow{8}{*}{ - } & $? 3-3$ to $4-2$ & \\
\hline & D. pentaradiatus & & $4-3$ to $4, \mathrm{CC}$ & \\
\hline & D. surculus & & $5-1$ to $5-2$ & \\
\hline & D. tamalis & & $5-3$ & \\
\hline & D. asymmetricus & & $6-2$ & \\
\hline \multirow{5}{*}{ 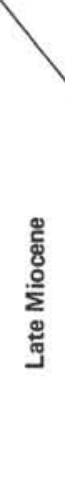 } & $\begin{array}{l}\text { A. primus to } \\
\text { A. tricorniculatus }\end{array}$ & & $6, \mathrm{CC}$ to $7-3$ & $1-1$ to $1, \mathrm{CC}$ (?) \\
\hline & A. primus & & $8-1$ & $2-1$ to $3-2$ \\
\hline & D. berggrenii & & $8, \mathrm{CC}(?)$ & $3-5$ to $4-1$ \\
\hline & D. neorectus & \multirow{2}{*}{$8-10(383-384)$} & \multirow{2}{*}{$9-2$ to $11-5$} & 45 \\
\hline & D. bellus & & & $5-1$ to $5, \mathrm{CC}$ (?) \\
\hline \multirow{5}{*}{ 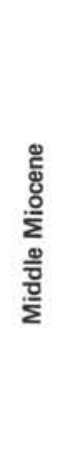 } & C. calyculus & \multirow{2}{*}{$\begin{array}{l}8-11(286) \text { to } \\
8-12(226-229) \\
\& 8-11(70-72) ?\end{array}$} & $11-6$ to $12-5$ & \multirow{3}{*}{ WASHED } \\
\hline & H. carteri & & - & \\
\hline & D. kugleri & $8-14(384-387)$ & 141 & \\
\hline & C. miopelagicus & $\begin{array}{l}8-15(34-37) \\
\text { to } 7-5(5)\end{array}$ & $14-2$ to $17, \mathrm{CC}$ & $6-1$ to $6-2$ \\
\hline & S. heteromorphus & - & $18-1$ to $18-2$ & $6-2$ to $12-1^{*}$ \\
\hline
\end{tabular}

Figure 5. Coccolith zonation for Guadalupe Island oceanic cores . (* indicates brackets basalt recovered in Cores 7 to 11 of Hole 470A. The Experimental Mohole Site [EM] was cored in 1961; the coccolith stratigraphy was reported in Martini and Bramlette [1963] and Martini [1971].)

Middle and lower upper Miocene assemblages of Holes 470 (Cores 11-18) and 470A (Cores 6, 7, 12) are warm temperate (like Site 469), on the basis of common discoasters and sparse Helicosphaera, Triquetrorhabdulus, and Sphenolithus heteromorphus. S. heteromorphus. S. heteromorphus (with secondary calcite overgrowths) is common only in Sample $470 \mathrm{~A}-7-1,1 \mathrm{~cm}$
$(166.5 \mathrm{~m})$, where its enrichment is considered to be a diagenetic effect at the expense of less durable species. Short-ranged Discoaster kugleri of the middle Miocene occurs in Sample 470-14-1, $7 \mathrm{~cm}(124 \mathrm{~m})$ and permits correlation to Core 90 of Site 467 .

The first record of low-latitude guide species Catinaster calyculus Martini and Bramlette s. str. and Dis- 
coaster hamatus Martini and Bramlette s. str. for Leg 63 permits direct identification of part of the Discoaster hamatus Zone between Samples 470-12-5, 50-51 cm $(110 \mathrm{~m})$ and $470-11-6,50-51 \mathrm{~cm}(105 \mathrm{~m})$. The basal $C$. calyculus in Sections 470-12-4 and 470-12-5 conform to the Martini and Bramlette-type suite but have straight rays instead of the more diagnostic curved rays. An occurrence of a curved-ray form in Core 13 is considered to be part of an in-hole slump. The upper Miocene Discoaster neohamatus Zone and Discoaster quinqueramus Zone also contain more common warm-water species that persist through thicker intervals than at Sites 467 and 469. Cool-water coccolith facies, rich in Reticulofenestra, Discoaster intercalaris Bukry, and D. variabilis Martini and Bramlette, however, are interspersed throughout these zones. Highlights of the upper Miocene, which was double cored in Hole 470A to fill in core-loss gaps for detailed studies, include the first reports of Catinaster mexicanus Bukry from the west coast of Mexico (Sample 470A-3,CC to Section 470A4-6). This rarely reported species was first described from DSDP Leg 1 cores from the Gulf of Mexico. The presence of large-sized Discoaster quinqueramus Gartner is established for the first time from the Guadalupe area in Section 470-8-1.

The difficulty in identifying the Miocene/Pliocene boundary by calcareous microfossils for Leg 63 persists at Site 470. The Amaurolithus primus Subzone to $A$. tricorricatus Zone interval that includes the boundary cannot be subdivided because the cool-water coccolith assemblages lack the key guide fossils-persistent $D$. quinqueramus and any Amaurolithus amplificus (Bukry and Percival) in the A. primus Subzone and any Triquetrorhabdulus rugosus Bramlette and Wilcoxon, $\mathrm{Ce}$ ratolithus acutus Gartner and Bukry, or C. rugosus Bukry and Bramlette in the A. tricorniculatus Zone.

The Pliocene section, according to coccoliths, begins with the Discoaster asymmetricus Subzone in Section 470-6-2. The Pliocene assemblages are warm temperate with a few C. rugosus Bukry and Bramlette in the Discoaster tamalis Subzone, abundant Discoaster pentaradiatus Tan in the Discoaster pentaradiatus Subzone, but Coccolithus pelagicus (Wallich) throughout. The top of the Pliocene is practically in Core 3 on the basis of the last common occurrence of Discoaster brouweri Tan and D. triradiatus Tan in Sample 470-4-1, $30 \mathrm{~cm}$ (29 m) (Haq et al., 1977). Calcidiscus macintyrei (Bukry and Bramlette), which marks the top of the Pliocene in the Mediterranean region (Bizon and Müller, 1978) and persists through the Emiliania annula Subzone (Bukry, 1973a), is common in Sample 470-3,CC but missing in Sample 470-2,CC.

The Quaternary coccolith assemblages of Cores 1 to 3 in Hole 470 are low-diversity, temperate assemblages characterized by $C$. pelagicus (Wallich), Calcidiscus leptoporus (Murray and Blackman), Emiliania annula (Cohen) (synonym = circular Pseudoemiliania lacunosa Kamptner, invalid fide Loeblich and Tappan, 1970), E. ovata Bukry, Gephyrocapsa caribbeanica Boudreaux and Hay, G. oceanica Kamptner, and Helicosphaera carteri (Wallich).

It is difficult to speculate on the geologic record of the California Current in this region, because there are no DSDP sites on the distal or oceanic side of the zone that was presumably occupied by the current. An observation on the paucity of seabirds and jellyfish at Site 470 suggests that it was not within the active, seasonal, high-fertility zone of the current ( $R$. Wolfart, personal communication, 1978) when drilling took place at this site. The Quaternary and Pliocene sediment of Site 470 show a persistence of coccoliths but only sporadic and rare diatoms and radiolarians. Does this imply that the site has not been under the current for 4 m.y., or that the current was weakened at these latitudes? Both possibilities assume that siliceous microfossils are the keys to identify the current. Coccolithophores persist whether upwelling is present or not.

High biogenic sedimentation rates could also be used to identify earlier tracks of the California Current. But, again, a reference site outside the distal margin of the current would help put into perspective the sedimentation values within the presumed area of the current.

On the basis of coccolith data from Site 470, the current during the middle Miocene was stable and moderately warm, the current during the late Miocene was unstable with alternating warm and cool phases, and during the Pliocene to the Quaternary, the current was unstable and weak and possibly located considerably east or west of Site 470 .

\section{Site 471 \\ $\left(23^{\circ} 28.93^{\prime} \mathrm{N}, 112^{\circ} 29.78^{\prime} \mathrm{W}\right.$, depth $\left.3101 \mathrm{~m}\right)$}

Coccoliths recovered at Site 471 represent only short intervals of time. The oldest assemblages, just above basalt, in Core 79 belong to the upper Sphenolithus heteromorphus Zone (approximately 14 Ma; Bukry, 1975). The overlying Coccolithus miopelagicus Subzone (approximately 13.4-14 Ma) extends through a thick interval from Core 39 to Core 78 (368-737 meters), but the short time span involved yields an exceptionally high sedimentation rate $(369 \mathrm{~m} / 0.6 \mathrm{~m} . \mathrm{y} .=615 \mathrm{~m} / \mathrm{m} . \mathrm{y}$.). In this interval (Lithologic Unit 4 in the Site 471 report), which is characterized by turbid-flow sedimentary structures, reworked Cretaceous and Paleogene coccoliths occur (Fig. 6). Another thick interval from Cores 6 to 39 (55-368 meters) is barren of coccoliths. Pleistocene to lower Pliocene coccoliths are sparse to abundant in the upper cores, Sample 1,CC to Core 6 (9.5-52 m), representing the time interval from approximately $0.5 \mathrm{Ma}$ to $4 \mathrm{Ma}$. The upper part of Core 1 was not investigated.

All sediment layers intercalated with the igneous rocks of Cores 80 to 88 that were examined for coccoliths are barren. The lower middle Miocene Sphenolithus heteromorphus Zone assemblages of Cores 78 and 79 are similar to overlying assemblages, except for the presence of Sphenolithus heteromorphus Deflandre, more common Cyclicargolithus floridanus (Roth and Hay), and the only observation of overgrowth ( +2 to 


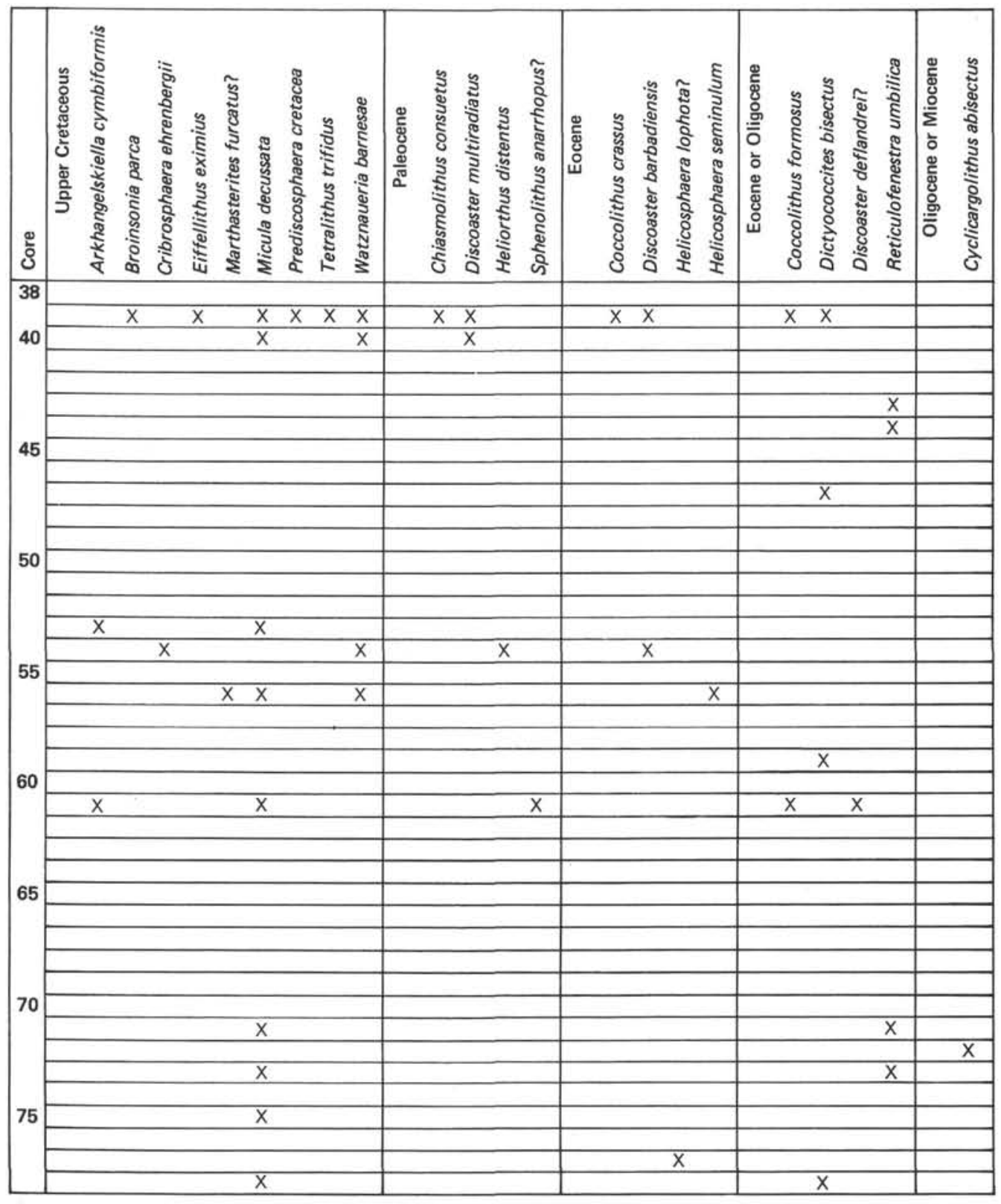

Figure 6. Upper Cretaceous and Paleogene reworked coccoliths from DSDP Site 471, Cores 38 to 78 (only every fifth core is numbered).

+3; Bukry, 1973a) at Site 471 (in Sample 471-79-1, $7 \mathrm{~cm}$ [751 m]; this sample also contains some fragments of pyritized centric diatoms).

Dark olive, clay-rich siltstone directly above basal, blue gray sandstone in the sequence of repeated similar turbidite units of the Coccolithus miopelagicus Subzone of Cores 39 to 78 yields the largest, most diverse coccoliths. Lighter-colored claystone from higher in the individual turbidite units yields mostly smaller less diverse coccoliths. Many sediment layers are barren or poor, producing an uneven record of abundance and preservation through the subzone. Reworked Cretaceous coccoliths in Cores 39 to 79 appear to represent Campanian to Maestrichtian horizons. Similar coccoliths occur onshore at San Diego (Bukry and Kennedy, 1969). Coc- coliths such as Discoaster multiradiatus Bramlette and Riedel indicate that upper Paleocene strata were a source of reworking.

Upper Pliocene assemblages are diverse, with up to 19 taxa recorded in some samples. Warm-water discoasters (such as $D$. decorus [Bukry] and $D$. blackstockae Bukry) occur, as do solution-susceptible taxa, such as Scyphosphaera, Syracosphaera, and even one Braarudosphaera in Sample 471-5-3, 50-51 cm (40 m). Lower Pliocene coccoliths of Cores 5 and 6 are common to abundant and etched. The assemblages are assigned to the Discoaster asymmetricus Subzone on the basis of Reticulofenestra pseudoumbilica (Gartner), Sphenolithus abies Deflandre, Discoaster tamalis Kamptner, and D. asymmetricus Gartner as deep as Sample 471- 
6-2, 50-52 cm (50 m). One reworked $A$. delicatus Gartner and Bukry occurs in Sample 471-5,CC. Coccoliths are missing in the interval from Sections 471-6-4 to 471-39-1, where carbonate occurs as rhombs and granules.

The Pliocene/Pleistocene boundary may be in a condensed section or cut out by a hiatus, because the Gephyrocapsa caribbeanica Subzone of Section 471-4-0 $(28.5 \mathrm{~m})$ overlies the Discoaster surculus Subzone of Sample 471-4-2, 52-53 cm (32 m). Pleistocene assemblages contain Gephyrocapsa oceanica Kamptner, having high-angle bars, and Coccolithus pelagicus (Wallich), indicating temperate influences.

\section{Site 472 \\ $\left(23^{\circ} 00.35^{\prime} \mathrm{N}, 113^{\circ} 59.71^{\prime} \mathrm{W}\right.$, depth $\left.3831 \mathrm{~m}\right)$}

To obtain a comparative pelagic record of the Neogene, Site 472 is located seaward of the terrigenous sedimentary sources that affected the area of Site 471 and, also, beyond the California Current. Unfortunately, no coccolith assemblages younger than middle Miocene are present, although a diverse, upper Miocene, biogenic siliceous record is preserved. Cores 1 to 9 of Hole 472 and Core 1 of Hole 472A are barren of coccoliths. Middle Miocene coccolith assemblages are common to abundant and moderately well preserved; these range from the Sphenolithus heteromorphus Zone just above basalt in Core $13(110-112 \mathrm{~m})$ to the Catinaster coalitus Zone in Core $10(82-91 \mathrm{~m})$. A limestone from Section $471-15-1$ is the only coccolith-bearing sediment recovered from the basalt interval at either Hole 472 or Hole $472 \mathrm{~A}$. The low-diversity assemblage is dominated by Cyclicargolithus floridanus (Roth and Hay) and represents a residuum of durable species that probably belongs to the overlying $S$. heteromorphus Zone. A $S$. heteromorphus Zone assemblage occurs in a black manganese oxide fragment in Sample 472-13,CC. The zone extends as high as Section 2 in Core 12 within the dark brown clay beds.

The overlying Coccolithus miopelagicus Subzone ranges from Section 472-12-2 (103 m) to Sample 472$11-1,10 \mathrm{~cm}(91 \mathrm{~m})$. C. floridanus is common throughout the subzone, suggesting that the top was not sampled. The most consistently occurring discoasters in the subzone are $D$. exilis Martini and Bramlette, D. sanmiguelensis $\mathrm{n}$. sp., and D. variabilis Martini and Bramlette. D. deflandrei Bramlette and Riedel and D. moorei Bukry are sparser, and $D$. signus Bukry, a warm-indicating species, is recorded only from the base of the subzone in Sample 472-12-2, $55 \mathrm{~cm}$ (103 m). D. signus does, however, occur through the underlying $S$. heteromorphus Zone, supporting the early middle Miocene Pacific warming shown by Douglas and Savin (1973) to have occurred in foraminiferal Zone N9, which is equivalent to the $S$. heteromorphus Zone. Catinaster coalitus Martini and Bramlette occurs in Sample 472-10,CC with Coccolithus sp. aff. C. miopelagicus Bukry, indicating the upper middle Miocene Catinaster coalitus Zone. Owing to poor recovery in Cores 10 and 11 , or to a hiatus, the intervening Discoaster kugleri Subzone is missing.

\section{Site 473 \\ $\left(20^{\circ} 57.92^{\prime} \mathrm{N}, 107^{\circ} 03.81^{\prime} \mathrm{W}\right.$, depth $\left.3249 \mathrm{~m}\right)$}

Site 473 on the Rivera plate west of Tres Marias Islands contains rare to common, poorly to moderately preserved Quaternary coccoliths in Cores 1 to $10(0-86$ $\mathrm{m})$. Preservation and abundance are worst in Cores 6 to $10(39-86 \mathrm{~m})$.

Upper Pliocene assemblages of Cores 11 to 15 (86$134 \mathrm{~m}$ ) are sparse to few, with evident solution effects. No lower upper Pliocene Discoaster tamalis Subzone assemblages occur. Because of the presence of Ceratolithus rugosus Bukry and Bramlette, Reticulofenestra pseudoumbilica (Gartner), and Sphenolithus abies Deflandre, Cores 16 to 18 (134-162 m) are assigned to the lower Pliocene. All three cores are tentatively assigned to the Sphenolithus neoabies Subzone because of the absence of younger Discoaster tamalis Kamptner and older Amaurolithus spp. The poor assemblages of Cores 19 to 22 and the lack of any Amaurolithus spp. in deeper cores make the duration of the S. neoabies Subzone and the placement of the Miocene/Pliocene boundary questionable.

Discoaster quinqueramus Gartner ranges through Cores 23 to 27 (191-238 m) and indicates the upper upper Miocene Discoaster quinqueramus Zone (approximately $5.6-7 \mathrm{~m} . \mathrm{y}$.) or possibly reworking and redeposition by turbidite flows during earliest Pliocene. Shipboard sedimentologists noted turbidite sequences in Cores 26 to 28. An in situ occurrence of the D. quinqueramus Zone is favored because of its presence through the overlying claystone of Cores 23 to 25 . This would yield an estimated age of 6 to $7 \mathrm{~m}$.y. at the top of the diabase sill in Core $29(248-252 \mathrm{~m})$. Core 28 is barren. And the sediment that was recovered in diabase Section $473-30-2$ is barren.

\section{UPPER CENOZOIC COCCOLITH ASSEMBLAGES FROM A PACIFIC COAST TRAVERSE}

The DSDP Pacific Coast Sites 173 and 467 to 473 provide the opportunity to compare assemblages of similar age at various latitudes from about $40^{\circ} \mathrm{N}$ to $20^{\circ} \mathrm{N}$. From the mid-Miocene to the Quaternary, many assemblage differences follow north-south trends, presumably related to temperature gradations along the coast (Addicott, 1970; Lynn, 1967). A group of coccolith genera was selected for survey counts of 100 specimens to assess changing ecologic controls on key stratigraphic taxa off the Pacific Coast. The seven genera selected are the source of the majority of the zonal guide species for the Miocene to Quaternary. The ratio of warm-indicator Discoaster to cool-indicator Coccolithus was calculated from these surveys. A second survey of 100 specimens counted all of the Discoaster species present, because some species like $D$. brouweri and $D$. signus are abundant under warm-water conditions, whereas others like $D$. intercalaris or $D$. variabilis are most numerous under temperate conditions.

Seven biostratigraphic zones or subzones through the Miocene to Quaternary were selected to provide maximum representation of the sites across latitude (Fig. 7). 


\begin{tabular}{|c|c|c|c|c|c|c|c|c|}
\hline \multirow{4}{*}{ Age } & \multirow{4}{*}{ Zone or Subzone } & Northern & \multicolumn{5}{|c|}{ DSDP Sites } & \multirow{2}{*}{$\begin{array}{c}\text { Southern } \\
473 \\
\end{array}$} \\
\hline & & 173 & 467 & 469 & 470 & 471 & 472 & \\
\hline & & \multicolumn{7}{|c|}{ Latitude N. } \\
\hline & & $39^{\circ} 57.71^{\prime}$ & $33^{\circ} 50.97^{\prime}$ & $32^{\circ} 37.00^{\prime}$ & $28^{\circ} 54.46^{\prime}$ & $23^{\circ} 28.93^{\prime}$ & $23^{\circ} 00.35^{\prime}$ & $20^{\circ} 57.92^{\prime}$ \\
\hline 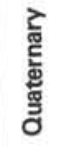 & $\begin{array}{c}\text { Emiliania } \\
\text { ovata } \\
\text { CN14a }\end{array}$ & $\begin{array}{c}3-2 \\
(70-71 \mathrm{~cm})\end{array}$ & $\begin{array}{c}5-3 \\
(50-51 \mathrm{~cm})\end{array}$ & $\begin{array}{c}4-2 \\
(50-51 \mathrm{~cm})\end{array}$ & $1, \mathrm{CC}$ & - & - & $5, \mathrm{CC}$ \\
\hline \multirow{2}{*}{ 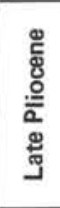 } & $\begin{array}{l}\text { Calcidiscus } \\
\text { macintyrei } \\
\text { CN12d }\end{array}$ & $\begin{array}{c}12-6 \\
(20-21 \mathrm{~cm})\end{array}$ & $\begin{array}{c}17 \cdot 3 \\
(50-51 \mathrm{~cm})\end{array}$ & $\begin{array}{c}7-1 \\
(50-51 \mathrm{~cm})\end{array}$ & $\begin{array}{c}4.1 \\
(30 \mathrm{~cm})\end{array}$ & - & - & $11, \mathrm{CC}$ \\
\hline & $\begin{array}{c}\text { Discoaster } \\
\text { tamalis } \\
\text { CN12a }\end{array}$ & $\begin{array}{c}13-6 \\
(17-18 \mathrm{~cm})\end{array}$ & $\begin{array}{c}25-3 \\
(9-10 \mathrm{~cm})\end{array}$ & $\stackrel{8-3}{(100-102 \mathrm{~cm})}$ & $\begin{array}{c}5 \cdot 3 \\
(50-51 \mathrm{~cm})\end{array}$ & $\begin{array}{c}4.5 \\
(100-102 \mathrm{~cm})\end{array}$ & - & - \\
\hline \multirow{2}{*}{ 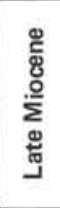 } & $\begin{array}{c}\text { Amaurolithus } \\
\text { primus } \\
\text { CN9b }\end{array}$ & $\begin{array}{c}15-4 \\
(20-21 \mathrm{~cm})\end{array}$ & $\begin{array}{c}52-1 \\
(50-51 \mathrm{~cm})\end{array}$ & $\begin{array}{c}13-1 \\
(50 \mathrm{~cm})\end{array}$ & $\begin{array}{c}8-1 \\
(75 \mathrm{~cm})\end{array}$ & - & - & $\begin{array}{c}27-1 \\
(76 \mathrm{~cm})\end{array}$ \\
\hline & $\begin{array}{c}\text { Discoaster } \\
\text { bellus } \\
\text { CN8a }\end{array}$ & $\begin{array}{c}19-4 \\
(20-21 \mathrm{~cm})\end{array}$ & $\begin{array}{c}73-1 \\
(45 \mathrm{~cm})\end{array}$ & $17, \mathrm{CC}$ & $\begin{array}{c}5 A-1 \\
(22 \mathrm{~cm})\end{array}$ & - & - & - \\
\hline \multirow{2}{*}{ 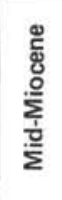 } & $\begin{array}{c}\text { Discoaster } \\
\text { kugleri } \\
\text { CN5b }\end{array}$ & $\begin{array}{c}21-3 \\
(20-21 \mathrm{~cm})\end{array}$ & $\begin{array}{c}90-2 \\
(25 \mathrm{~cm})\end{array}$ & $\begin{array}{c}19-1 \\
(20-21 \mathrm{~cm})\end{array}$ & $\begin{array}{c}14-1 \\
(7 \mathrm{~cm})\end{array}$ & - & - & - \\
\hline & $\begin{array}{l}\text { Sphenolithus } \\
\text { heteromorphus } \\
\text { CN4 }\end{array}$ & $\begin{array}{c}29-2 \\
(20-21 \mathrm{~cm})\end{array}$ & $100, \mathrm{CC}$ & $25, \mathrm{CC}$ & $\begin{array}{c}18-2 \\
(69-70 \mathrm{~cm})\end{array}$ & $\begin{array}{c}79-1 \\
(34 \mathrm{~cm})\end{array}$ & $\begin{array}{c}12-2 \\
(59-61 \mathrm{~cm})\end{array}$ & - \\
\hline
\end{tabular}

Figure 7. Array of samples used to compare changes in coccolith assemblages from DSDP Pacific Coast sites for different zonal time slices. (Water depths from $2927 \mathrm{~m}$ at Site 173 to $3249 \mathrm{~m}$ at Site 473 are variable [see site summaries] and show no direct correlation between latitude and depth, although the three northern sites are shallowest.)

Calcareous microfossil assemblages of similar age for each zone or subzone are available for comparison at Sites 173 and 467 to 470 . Several gaps occur in the stratigraphy of southern Sites 471 to 473 because of dissolution and erosion.

Time slices involving samples in which coccoliths are not zonally diagnostic (e.g., younger intervals of Site 173) are correlated using diatom stratigraphy for the sites (Barron, this volume).

The Quaternary Emiliania ovata Subzone (CN14a) is the youngest unit studied. Among the genera selected for counting, Coccolithus is considered the cool-indicating taxon because of its Holocene limitation to waters colder than $14^{\circ} \mathrm{C}$ in the Atlantic (McIntyre et al., 1970). Helicosphaera is generally considered a warm-water taxon $\left(20^{\circ} \mathrm{C}-28^{\circ} \mathrm{C}\right)$, however, its range does extend as low as $8^{\circ} \mathrm{C}$ (Roth and Berger, 1975). Its high relative abundance at southern Sites 470 and 473 (Fig. 8) supports warm-water conditions, but the additional presence of numerous Pontosphaera and Thoracosphaera and reworked Cenozoic coccoliths could also indicate increased coastal turbidity as a factor contributing to its abundance.

A dramatic change in the Discoaster/Coccolithus ratio from Site 173 southward to Site 473 in the uppermost Pliocene Calcidiscus macintyrei Subzone CN12d (Fig. 9) shows a strong temperature gradient (i.e., warmer to the south), second only to that indicated for lower upper Pliocene CN12a. The large 50\% abundance of Helicosphaera at northern Site 173 is based on a great

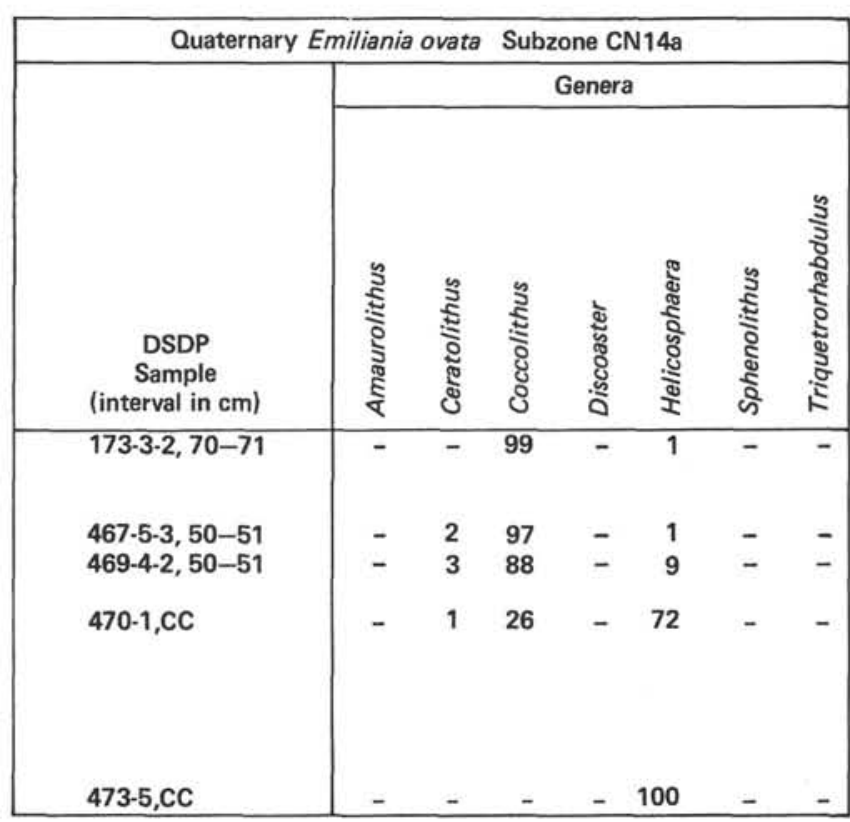

Figure 8. Percentages of selected coccolith genera in Pacific Coast assemblages of Subzone CN14a. (Values for each sample are from a survey of 100 specimens of selected genera. Samples are arrayed according to latitudinal location, with north at the top.)

bloom of the species $H$. sellii at high mid-latitudes. This same nannofacies, with Coccolithus pelagicus and $H$. sellii dominant, also occurs in DSDP Leg 12 in the North Atlantic (Bukry, 1972a) near the Pliocene/Pleis- 


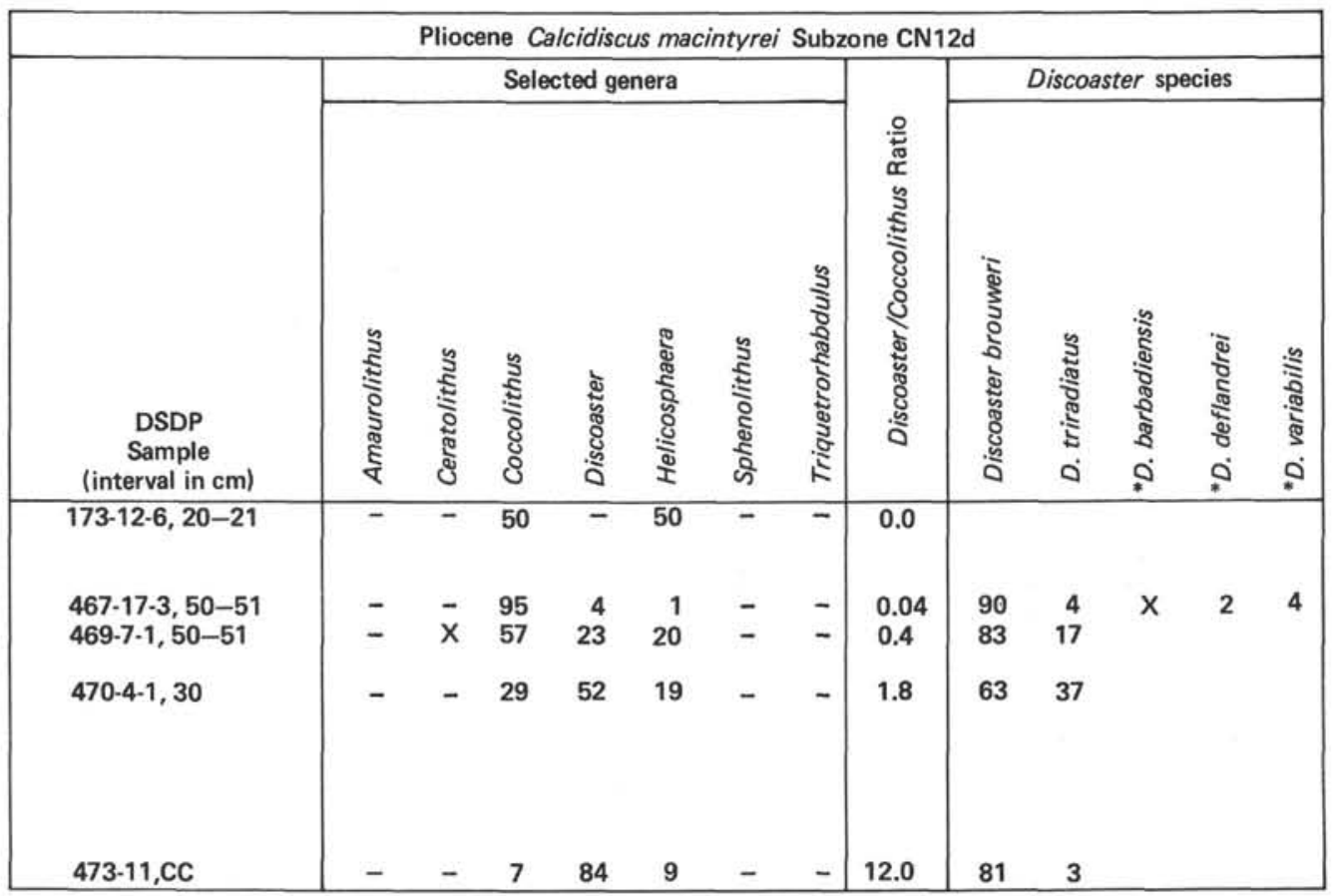

Figure 9. Percentages of selected coccolith genera in Pacific Coast assemblages of Subzone CN12d. (Values for each sample are from a survey of 100 specimens of the selected genera. The Discoaster/Coccolithus ratios calculated from these values suggest a north-south paleotemperature trend. All of the Discoaster species encountered in a separate 100 -specimen count are enumerated. ${ }^{*}=$ Reworked taxon; $X=$ recorded as present after the 100-specimen count was completed.)

tocene boundary. The variance in the proportions of Discoaster brouweri and D. triradiatus could represent a bracketing of a fairly narrow habitat for $D$. triradiatus by this traverse, a random selection of samples from various levels in the late Pliocene acme of $D$. triradiatus, or, less likely, variations in $D$. brouweri productivity at sites within the traverse.

The reversal in the Discoaster/Coccolithus ratio for the Discoaster tamalis Subzone CN12a (Fig. 10) occurs between Sites 467 and nearby Site 469 . The degree of change in the ratio is large, as are the end-member values for Sites 173 and 471 , indicating a strong north to south temperature gradient of warming. The restriction of warm-water species Discoaster blackstockae, D. pentaradiatus, and Hayaster perplexus to southerly Sites 469,470 , and 471 further emphasizes the temperature trend present in the generic count.

The Discoaster/Coccolithus ratio is less discriminating in the upper Miocene Amaurolithus primus Subzone $\mathrm{CN} 9 \mathrm{~b}$ than in shallower levels but suggests that the traverse region was relatively warm. Although discoasters were abundant, the count of species shows that temperate species $D$. intercalaris and $D$. variabilis are dominant in all but the southernmost site (Fig. 11) where $D$. quinqueramus is predominant.

Discoaster, dominated by temperate $D$. variabilis, is abundant throughout the traverse for the lower upper Miocene Discoaster bellus Subzone CN8a (Fig. 12). The concentration of warm-water species Catinaster calyculus, Discoaster bellus, D. blackstockae, and D. neo- hamatus in southern sites and their absence at northernmost Site 173 suggests a temperature gradient. But the Discoaster/Coccolithus ratio gives a cooler value for Site 470 than for Sites 467 or $\mathbf{4 6 9}$. Therefore the generic ratio that was a convenient and consistent measure for the Pliocene is not as useful for the late Miocene of these sites. The change is likely the result of the evolution of different habitat requirements of new biologic species of the genera upsection. Another factor affecting the ratio could be carbonate solution, which may differentially remove somewhat more Coccolithus than Discoaster. Comparison of carbonate percentages from cored sediments to respective Discoaster/Coccolithus ratios is not a straightforward measure of carbonate solution, because of the terrigenous and volcanogenic dilution at many sites. But with this proviso in mind, a paleotemperature significance for the ratio does seem to override any solution effect for Subzone CN8a. The carbonate percentage and Discoaster/Coccolithus ratio, respectively, for Sites $173,467,469$, and 470 are $12 \%$ and $2.4,61 \%$ and $14.5,77 \%$ and $17.7,41 \%$ and 6.3 . This relation shows the higher proportion of Discoaster with the higher carbonate percentages. The results for other zones are mixed or show the opposite trend. For example Subzone $\mathrm{CN} 12 \mathrm{~d}$ has the following values for Sites $173,467,469,470$, and $473: 14 \%$ and $0.0,40 \%$ and $0.04,38 \%$ and $0.4,16 \%$ and 1.8 , and $8 \%$ and 12.0 . The last three sets match higher proportions of Discoaster with lower carbonate percentages, which could be caused by paleotemperature and/or solution. The 


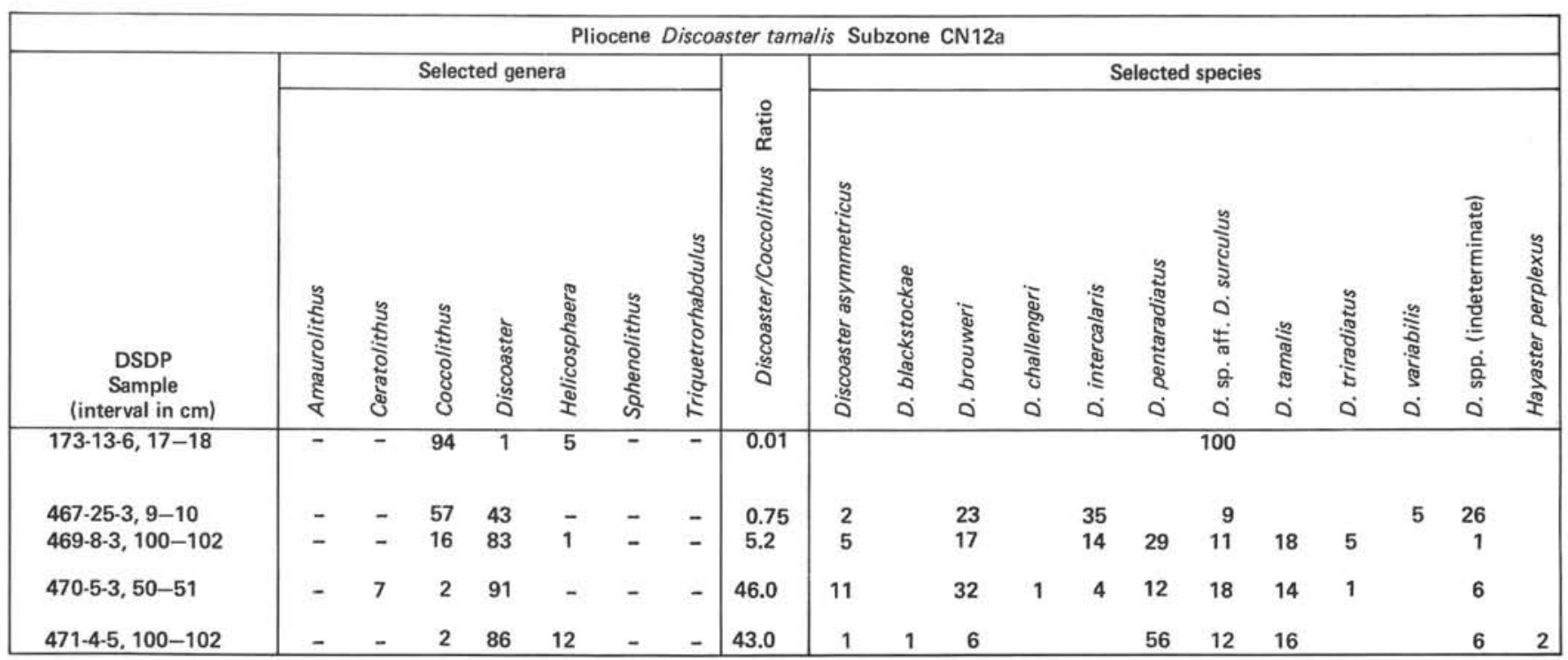

Figure 10. Percentages of selected coccolith genera in Pacific Coast assemblages of Subzone CN12a. (Values for each sample are from a survey of 100 specimens of the selected genera. Large differences in the Discoaster/Coccolithus ratios occurred in Subzone CN12a from north to south. All of the Discoaster and tropical Hayaster species encountered in a separate 100-specimen count are enumerated [the lone Discoaster specimen in the generic count for Site 173 precluded a 100 count].)

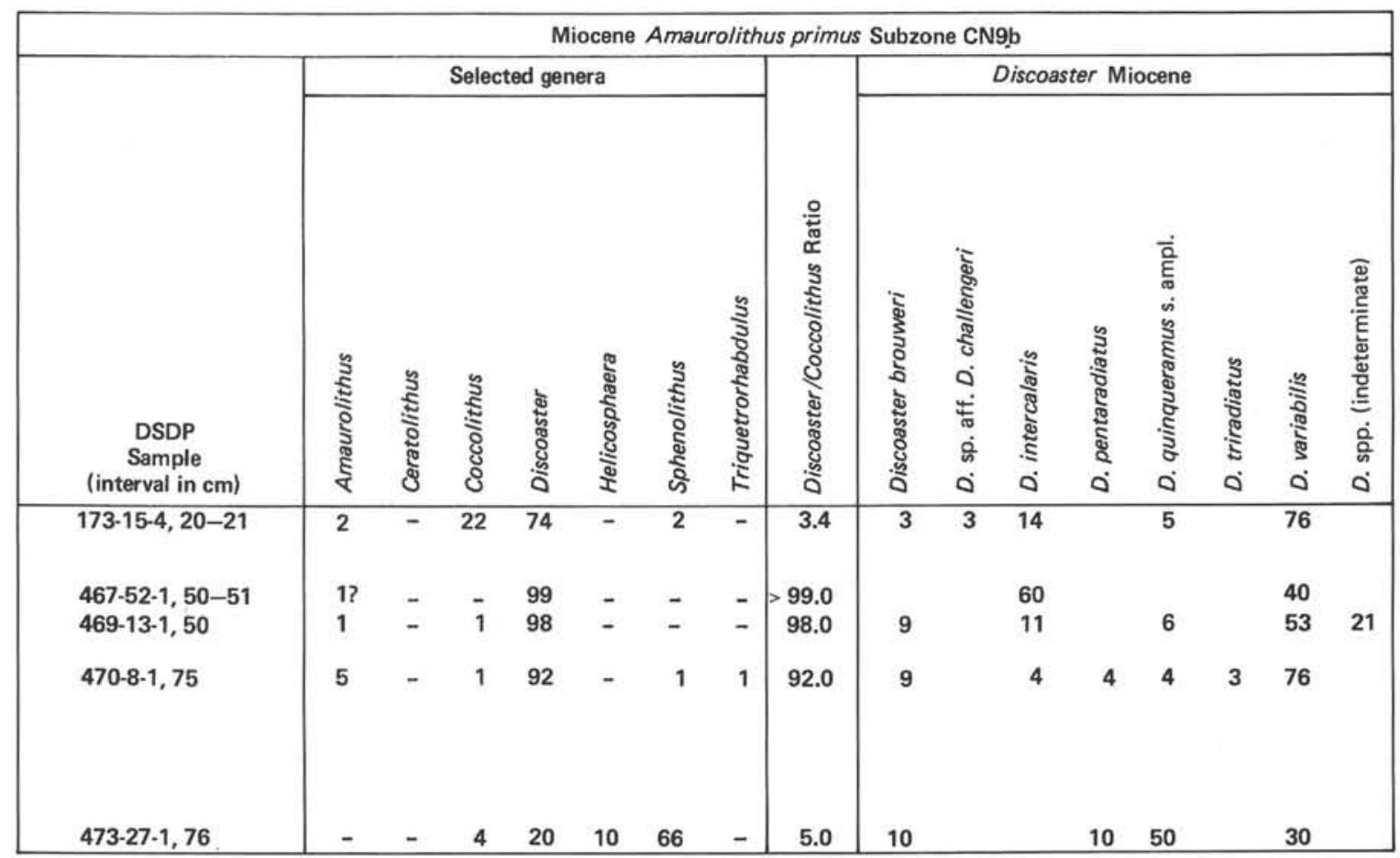

Figure 11. Percentages of selected coccolith genera in Pacific Coast assemblages of Subzone CN9b. (Values for each sample are from a survey of 100 specimens of the selected genera. A predominance of temperate species Discoaster intercalaris and D. variabilis among the discoasters suggests that the temperature indicating capability of the Discoaster/Coccolithus ratio is poorer for the Miocene than the Pliocene. The Discoaster species count for Site 473 is part of the generic count, owing to the sparsity of specimens in the terrigenous-rich sediment.)

values for Site 467 suggest the opposite trend, with temperature overriding any solution effect. More detailed work on this relation should be done in future studies using coccoliths to analyze paleoenvironment.

An additional factor that might account for the reversals in Zone CN8, for example, are high-frequency climatic oscillations during the interval examined. Preliminary comparisons of climatic indices from foraminifers, diatoms, and silicoflagellates indicates a highfrequency oscillation during Subzone CN8a (Richard Z. Poore, personal communication, 1980). Therefore, the sampling of different parts of the climatic curve at dif- 


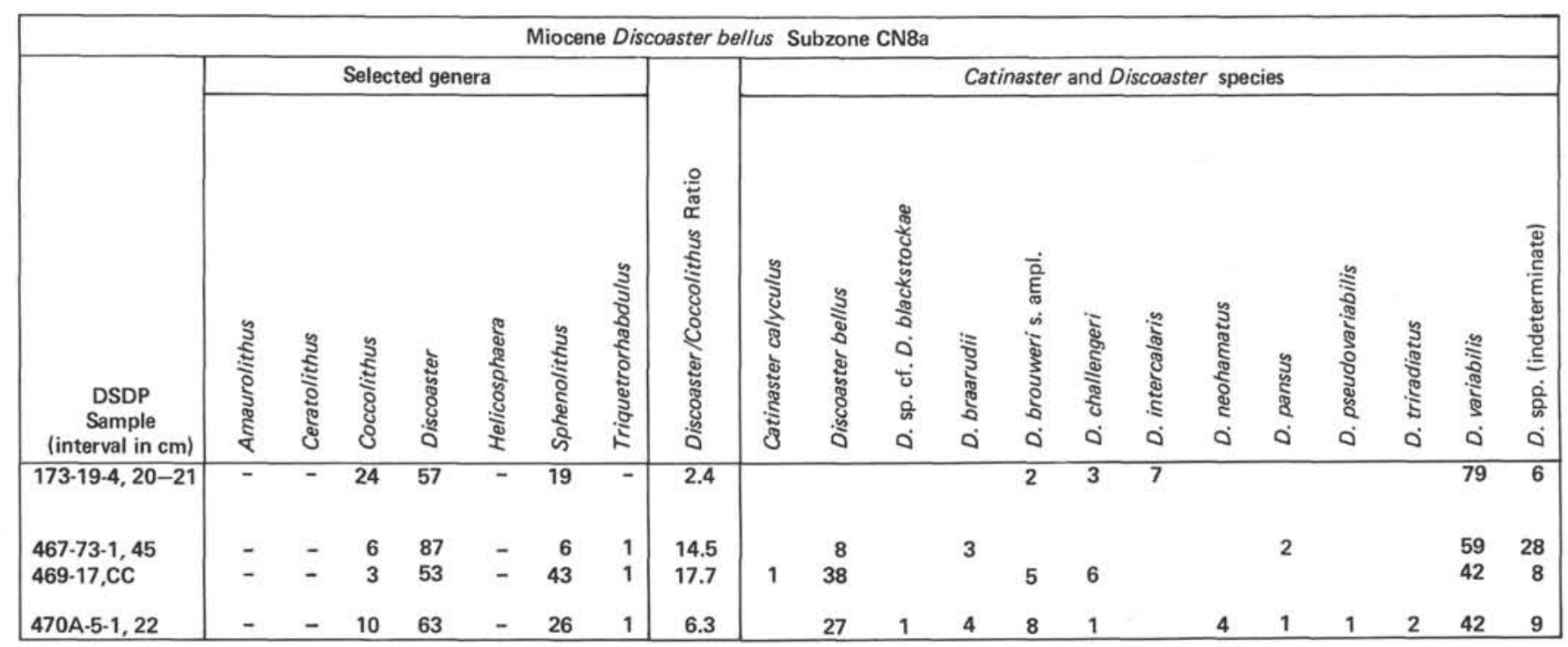

Figure 12. Percentages of selected coccolith genera in Pacific Coast assemblages of Subzone CN8a. (Values for each sample are from a survey of 100 specimens of the selected genera. Relative values for the Discoaster/Coccolithus ratio do not show a consistent north-south trend, but the high value for Site 469 is supported by the occurrences of warm-water Catinaster calyculus and Discoaster bellus. All of the Catinaster and Discoaster species encountered in a separate 100-specimen count are enumerated.)

ferent sites could easily produce apparent reversals. Establishing these relations will require detailed work beyond the scope of this initial report.

The northern four sites of the Pacific Coast traverse recovered assemblages of, or correlative to, the relatively brief mid-Miocene Discoaster kugleri Subzone CN5b. Discoaster species are similar at sites south of Site 173 ; D. kugleri is missing at Site 173 , which was correlated by diatom stratigraphy (Barron, this volume). A high Discoaster/Coccolithus ratio at Site 173 (Fig. 13) seems to indicate warm-water conditions, whereas the low diversity of the assemblages is more typical of cool-water conditions. The exceptionally high Discoaster/Coccolithus ratios at all four sites were checked against tropical Pacific Site $77\left(00^{\circ} 28.90^{\prime} \mathrm{N}\right)$. This tropical Discoaster/Coccolithus ratio for Subzone CN5b is dramatically lower than for the Pacific Coast traverse sites, indicating that the Coccolithus species $C$. miopelagicus and $C$. pelagicus (s. ampl., small) tolerated warm water and cannot be employed as strictly cool-water indicators for the middle Miocene. Clearly, the center of the biogeographic range of Coccolithus changed considerably from the middle Miocene to the Quaternary.

A comparison of Zone CN4 at California Continental Borderland Site 470 and nearby Sites 471 and 472 to equatorial Pacific Site 77 (Hole 77B) shows that the numbers of $C$. miopelagicus and $C$. pelagicus s. ampl. are as high at the equatorial site as at the southernmost traverse sites: $12 \%$ to $25 \%$ of the selected genera count at Hole 77B (Cores 25-27), $11 \%$ to $13 \%$ at Sites 471 and 472 , and up to $60 \%$ at Site 470 . The Discoaster/Coccolithus ratios for Zone CN4 at Hole 77B (Cores 25-27) are also similar but lower, with values of 1.0 to 2.4 . These similarities between the assemblages (owing to the broader range of Coccolithus in the lower middle Miocene) are only apparent because the equatorial assemblages can be discriminated by using their much greater abundances of Sphenolithus. For example, compare the following Sphenolithus (S), Discoaster (D), Coccolithus (C) values from the selected genera counts to those of Leg 63: Samples 77B-25-2, 20-22 cm, S $=64 \%, D=$ $14 \%, \mathrm{C}=19 \% ; 77 \mathrm{~B}-25-6,94-98 \mathrm{~cm}, \mathrm{~S}=50 \%, \mathrm{D}=$ $24 \%, \mathrm{C}=25 \% ; 77 \mathrm{~B}-27-4,67-68 \mathrm{~cm}, \mathrm{~S}=59 \%, \mathrm{D}=$ $29 \%, \mathrm{C}=12 \%$.

Evidence of a change, or evolution, in the optimum temperature preference of Coccolithus species can be seen in the total absence of Coccolithus in the upper Pliocene Subzone CN12a at equatorial Site 77 (Sample $77 \mathrm{~B}-4-6,70-71 \mathrm{~cm})$. On the other hand, Coccolithus is present at all Pacific Coast traverse sites with increasing abundance northward. The $14^{\circ} \mathrm{C}$ limitation of modern Coccolithus certainly did not apply to the substantial middle Miocene (Zones CN4 and CN5) populations of Coccolithus found at equatorial Site 77 . The difference in representation of the genus at equatorial sites between the Miocene and Pliocene is a matter of changing temperature tolerance of biologic species evolving in the genus.

An interval from the upper Sphenolithus heteromorphus Zone CN4 of the middle Miocene was compared across six DSDP sites included in a Pacific Coast traverse (Fig. 14). Discoaster exilis is dominant in all of the discoaster assemblages, however, warm-water $D$. signus is limited to the three southern sites, suggesting the existence of a temperature gradient. Solution was strongest at northern Site 173 where Coccolithus may have been differentially dissolved, because the highly resistant placoliths of Cyclicargolithus and Reticulofenestra are fragmented and etched. As in other Miocene in- 


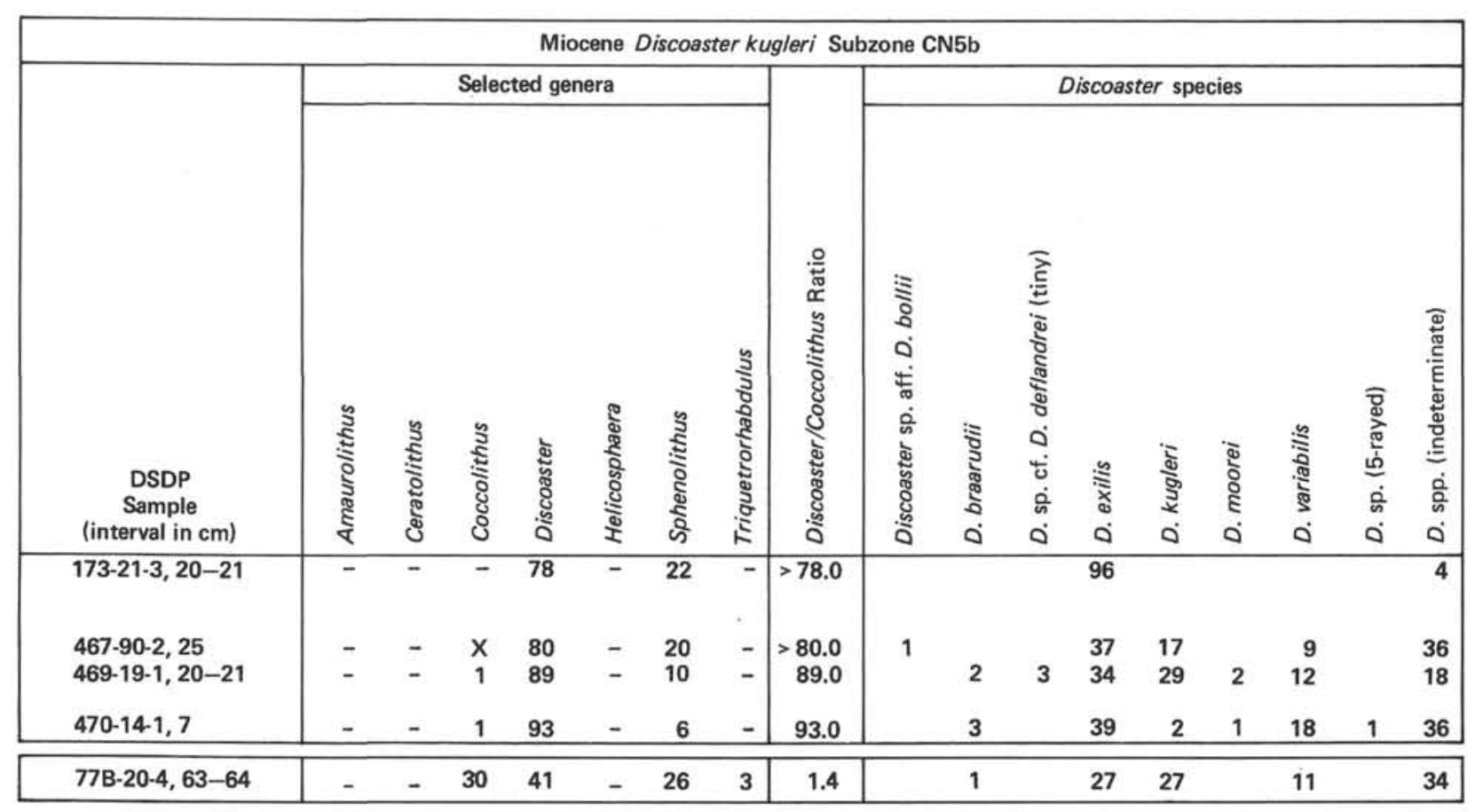

Figure 13. Percentages of selected coccolith genera in Pacific Coast and tropical Pacific (Site 77) assemblages of Subzone CN5b. (Values for each sample are from a survey of 100 specimens of the selected genera. All of the Discoaster species encountered in a separate 100-specimen count are enumerated. Discoaster kugleri is exceptionally common at Sites 77, 467, and 469. All four Pacific Coast assemblages are dominated by Reticulofenestra placoliths and fragments; Coccolithus is extremely sparse [X = recorded as present after the 100-specimen count was completed]. Tropical Site 77, however, contains a significant number of Coccolithus miopelagicus and C. pelagicus [s. ampl., small].)

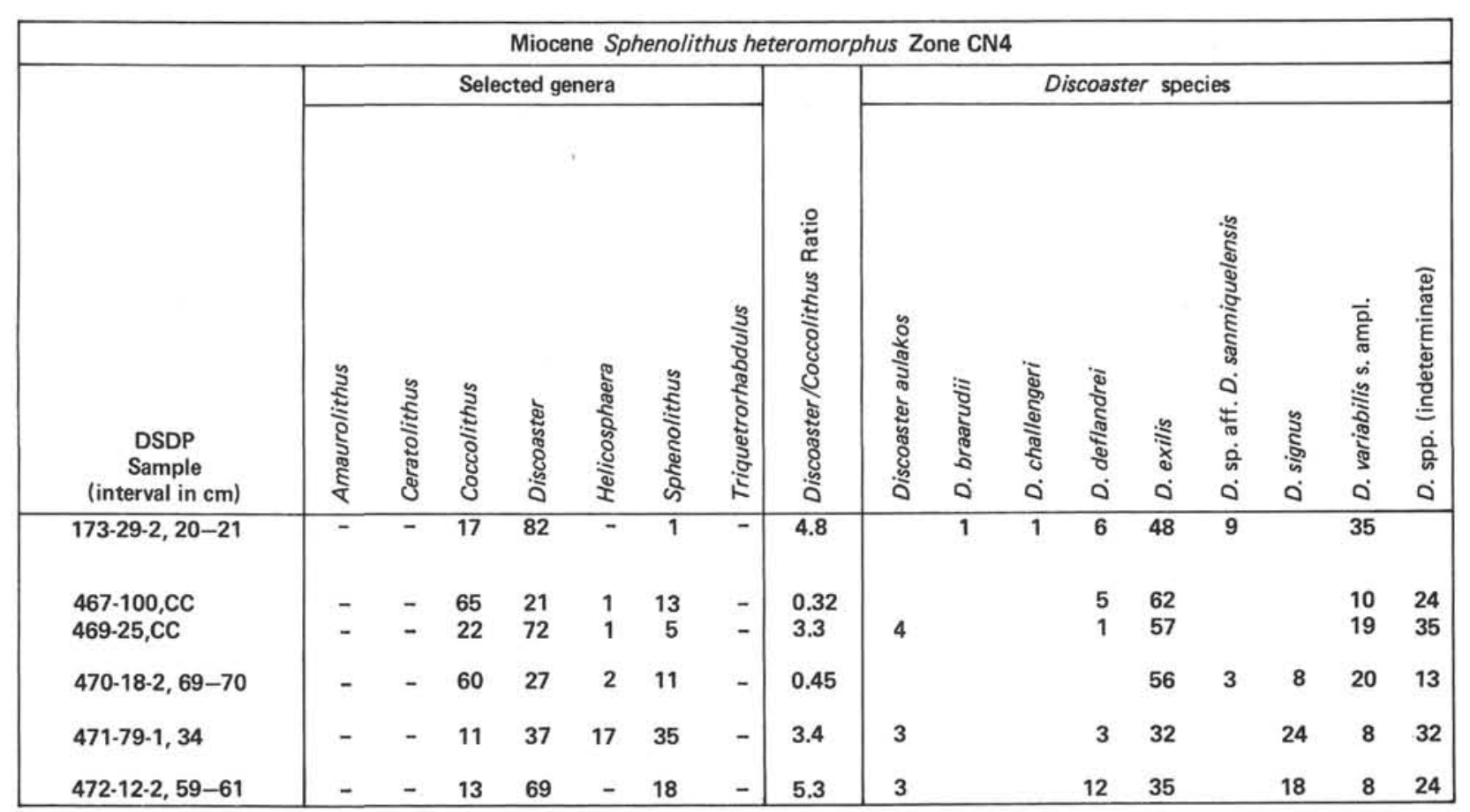

Figure 14. Percentages of selected coccolith genera in Pacific Coast assemblages of Zone CN4. (Values for each sample are from a survey of 100 specimens of the selected genera. Discoaster/Coccolithus ratios show a narrow range of variation but also show apparent reversals. The tropical Discoaster D. signus is limited to southern sites off Baja California. All of the Discoaster species encountered in a separate 100-specimen count are enumerated.) 
tervals examined, the Discoaster/Coccolithus ratio for Zone CN4 does not show a consistent gradient across latitude; high and low ratios are interspersed.

This brief survey of 35 samples from eight upper Cenozoic sites involved counts of only 7,000 specimens from seven selected biostratigraphic units, but shows north-south gradients of Discoaster species for all intervals. The distribution of species of Discoaster is most helpful in identifying warm- and cool-water regimes at different times. The affinity of Coccolithus for coolwater (McIntyre et al., 1970) had evolved by the Pliocene, making the Discoaster/Coccolithus ratio an effective measure of paleotemperature trends through the $20^{\circ}$ latitude of the traverse region for the Pliocene. In older Miocene assemblages, the temperature affinities of the species of Coccolithus appear to have been broader, with persistent occurrence into the tropics. Variable depths and dissolution histories at the sites, and even potential tectonic translations across latitude (Crouch, 1979), could have altered the trends, but the Discoaster species appear to be a consistent guide through the space-time matrix surveyed.

The key area in the traverse is between Site 467 and 470 , near the outer California Continental Borderland. Reversals in abundance trends for indicator taxa for all the zones and subzones above upper Miocene Subzone $\mathrm{CN} 8 \mathrm{a}$ are located between those sites. Older intervals are less clear. Some sites off central California are needed to assess biogeographic ranges for older intervals. The strongest gradients occur in the intervals examined from the Quaternary and upper Pliocene.

\section{SYSTEMATIC PALEONTOLOGY}

\section{Genus CALCIDISCUS Kamptner, 1950}

Remarks. In their report explaining the priority of Calcidiscus over Cyclococcolithus and Cyclococcolithina, Loeblich and Tappan (1978) transferred several recently described circular placoliths to Calcidiscus. Many of the other species assigned to this genus will likely be transferred elsewhere in future studies because of the specialized ultrastructure and crystallography of the type species, Calcidiscus leptoporus (Murray and Blackman), and of the similar species C. macintyrei (Bukry and Bramlette), both from the upper Cenozoic. Although a detailed study is not presented here, some of the obvious candidates for reassignment are indicated.

The partly obscured transmission electronmicrograph of the Upper Cretaceous species Calcidiscus clockiradialis (Huh) has rim and central area structures unrelated to Calcidiscus.

The Eocene and Oligocene species Calcidiscus formosus (Kamptner) and Calcidiscus orbis (Gartner and Smith) are synonyms and, on the basis of ultrastructure, should be assigned to Coccolithus (see synonymy and discussion by Wise, 1973).

Genus CATINASTER Martini and Bramlette, 1963 Catinaster mexicanus Bukry

(Plate 1, Figs. 1-3)

Catinaster mexicanus Bukry, 1971b, p. 50, pl. 3, figs. 7-9.

Catinaster mexicanus Bukry, Ellis, Lohman, and Wray, 1972, p. 37, pl. 10 , fig. 1.

Remarks. Catinaster mexicanus occurs in the Gulf of Mexico DSDP Site 3, Core 9, Sections 2 and 3 in a brief interval in upper Miocene Zone CN9. The presence of C. mexicanus at DSDP Site 470 (in Sample 470A-3,CC to Section 470A-4-6) is also associated with upper Miocene coccoliths of Zone CN9 and CN8. Both occurrences are below the appearance of Amaurolithus. This species is rarely reported. A single specimen of Catinaster sp. (Plate 1, Fig. 4) lacks the characters of presently described species.
Genus CRENALITHUS Roth, 1973

Crenalithus taganus (Fonseca) n. comb. (Plate 6, Figs. 16-17?)

Coccolithus taganus Fonseca, 1976, p. 29, pl. 1, figs. 1-8. Reticulofenestra haqii Backman, 1978, pl. 1, figs. 1-4; pl. 2, fig. 10 .

Remarks. There is uncertainty about the taxonomic identifications and utility of very small placoliths. The lack of certitude from photomicroscope study arises from the inability to discern diagnostic features in order to differentiate among the small placoliths of different epochs and subepochs. There may be overlap and intergradation between the very generalized small $(1-5 \mu \mathrm{m})$ placolith species. For example, lower Miocene Crenalithus taganus (Fonseca) is structurally like lower Miocene to Pliocene Reticulofenestra? haqii Backman. Both have very small central openings with no evident grill. The difficulty distinguishing subtle variations in size and proportions of rim and central area between such species is, of course, compounded by overgrowth or solution.

Because of the perception that small placoliths provide little information relative to the difficulty in unambiguously identifying them for every sample, they have been treated as general species groups for studies in paleoecologic variations (Haq and Lohmann, 1976). Detailed studies of ultrastructure, crystallography, and evolutionary lineages still need to be done for the numerous small placoliths that have been proposed, such as Coccolithus minutulus Gartner (1967) and Crenalithus productellus Bukry (1975).

Crenalithus taganus has ultrastructure that suggests closer affinities to Crenalithus (bright distal shield in cross-polarized light) than to Coccolithus (type species $C$. pelagicus [Wallich]; see the discussion of crystallography by Hay, Mohler, and Wade, 1966). Crenalithus differs from Reticulofenestra by the lack of any regular fenestrate grill (type species $R$. caucasica Hay, Mohler, and Wade; see the particular morphology of this grill in Hay, Mohler, and Wade, 1966, and in Perch-Nielsen, 1971, as R. umbilica). Genus Crenalithus, with its type species $C$. doronicoides, is constructed more similarly to C. taganus and is a better classification for these small, simple placoliths.

The generic names Coccolithus, Cyclicargolithus, Dictyococcites, and Reticulofenestra are also applied to species other than small placoliths without the presence of requisite diagnostic characters. For example, the large middle Tertiary placoliths with a prominent bright distal shield (cross-polarized light), Cyclicargolithus abisectus (Müller) Wise (1973), is still called Coccolithus abisectus by some authors (Müller, 1978). The numerous Cenozoic species proposed within genus Reticulofenestra are based primarily on differences in size and proportions of the rim and central area. The central area, however, can be filled in, due to natural changes in proportions or to overgrowth by secondary crystallites, producing closed and open species in the same sample (Bukry, 1972b). This effect occurs in both large and small members of the species. It is doubtful whether consistent species identifications would be achieved in this genus if the ages of samples were not already established by other criteria.

Crenalithus taganus or similar placoliths occur in most of the Leg 63 coccolith assemblages.

\section{Genus DISCOASTER Tan, 1927}

Discoaster okadai n. sp.

(Plate 1, Figs. 5-11; Plate 2, Figs. 1-6)

Discoaster sp. 2, Okada and Thierstein, 1979, p. 523, pl. 5, fig. 7; pl. 15 , fig. 12.

Description. Discoaster okadai is a very large 4- to 7-ray discoaster. The straight rays are long, thin, and tapered, with simple pointed tips. There is no apparent central-area knob or ornamentation. Many specimens show asymmetry from regular equiangular arrangement of the rays. Five-rayed forms are most abundant, with 4-, 6-, and 7-rayed forms occurring in smaller quantities.

Remarks. Discoaster okadai was first observed in DSDP Hole 47.2 in the Pacific (Bukry, unpublished data, 1969) but was considered a local aberrant form. Publication of an identical specimen of the same Paleocene age from Atlantic DSDP Site 384 (Okada and Thierstein, 1979), however, confirms a transoceanic significance for this species. D. okadai is distinguished from other large Paleogene species, such as D. tanii Bramlette and Riedel and D. nodifer (Bramlette and Riedel), by pointed tapering rays lacking any ornamentation, and from $D$. lo- 
doensis Bramlette and Sullivan by the straight, nonridged rays and lack of a central knob. Owing to overgrowth on discoasters at DSDP Sites 47.2 and 384 , there is some resemblance to overgrown Neogene specimens of $D$. hamatus or $D$. neorectus Bukry; larger central areas help to distinguish these later species. Because of the large size and distinctive, long, free rays of $D$. okadai, it is easily discriminated from other Paleocene discoasters.

Occurrence. Discoaster okadai is known from the upper Paleocene Zone CP7 in Hole 47.2 in the North Pacific (Bukry, unpublished data, 1969) and from the same Zone CP7 at North Atlantic Site 384, with sparse specimens ranging into overlying Subzone CP8a (Okada and Thierstein, 1979). This close correlation in transoceanic occurrences suggests a biostratigraphic value for $D$. okadai.

Size. Maximum diameter: 20 to $45 \mu \mathrm{m}$ (holotype $39 \mu \mathrm{m}$ ).

Holotype. USNM 307287 (Plate 2, Fig. 6).

Isotypes. USNM 307288 to 307301 .

Type locality. Northwestern Pacific Ocean, DSDP Sample $47.2-8-6,78-80 \mathrm{~cm}(82 \mathrm{~m})$.

Discoaster sanmiguelensis n. sp.

(Plate 2, Figs. 7-10; Plate 3, Figs. 1-14)

Description. Discoaster sanmiguelensis has six short, broadly tapered rays with a slight indentation or slight bifurcation at the tips. The interray areas are broadly rounded. A large, star-shaped knob dominates the central area of one side of the asterolith; the knob rays point to the interray areas on most specimens.

Remarks. Discoaster sanmiguelensis is characterized by short, slightly bifid rays and a large, central-area knob on one side. It is distinguished from similar species Discoaster bollii Martini and Bramlette by less bifid rays and the lack of knobs on opposite sides, from $D$. kugleri Martini and Bramlette by a large knob, from D. adamanteus Bramlette and Wilcoxon by narrower bifid rays, from $D$. altus Müller by bifid rays and knob-ray alignment, from $D$. deflandrei Bramlette and Riedel by larger knob and much narrower ray tips, from $D$. formosus Martini and Worsley by shorter rays and smaller size, from $D$. stellulus Gartner by larger knob and bifid ray tips, and from $D$. toralus Ellis, Lohman, and Wray by larger knob and tapered, small, bifid ray tips.

Occurrence. Discoaster sanmiguelensis is known from the California Continental Borderland in strata of middle Miocene Zone CN5 and uppermost Zone CN4. The most prominent Leg 63 occurrences are at Site 468 in Cores 2 to 9, assigned to Subzone CN5a. It also occurs in USGS borderland dart cores S3-79-SC-259 and -312 from CN4 and $\mathrm{CN} 5 \mathrm{a}$, respectively.

Size. Maximum diameter: 9 to $15 \mu \mathrm{m}$ (holotype $10 \mu \mathrm{m}$ ).

Holotype. USNM 307302 (Plate 3, Figs. 2, 3).

Isotypes. USNM 307303 to 307314.

Type locality. California Continental Borderland DSDP Sample $468-9, \mathrm{CC}(79 \mathrm{~m})$.

\section{Discoaster tridenus Kamptner, emended}

$$
\text { (Plate 3, Figs. 15-17) }
$$

Discoaster tridenus Kamptner, 1967, p. 166, text-fig. 30.

Discoaster brouweri tridenus (Kamptner) Hay, 1970, p. 461.

Remarks. This symmetric, five-rayed discoaster has long, slender, curved rays, little or no central area, and a very small central plug that was not illustrated in the original drawings. In cross-polarized light, the apparent birefringence of the five ray-crystallites is fainter than that associated with specimens of Discoaster pentaradiatus Tan. By size and structure, $D$. tridenus is related to $D$. brouweri Tan.

An unusually large abundance of $D$. tridenus is noted in DSDP Sample 470-5-2, 50-51 cm $(40 \mathrm{~m})$, which is assigned to lower Subzone $\mathrm{CN} 12 \mathrm{~b}$. A lack of $D$. asymmetricus Gartner in this sample implies some threshold relation between the symmetric and asymmetric members of the $D$. brouweri group. $D$. tridenus occurrences may be poorly recorded, in part, because of general similarity to $D$. pentaradiatus with broken or poorly developed tips or because of lumping the typically small numbers of five-rayed forms with the more dominant six-rayed $D$. brouweri. See Hay and Beaudry (1973) for a quantitative evaluation of $D$. tridenus in the Pliocene. Miocene references to $D$. tridenus at DSDP Site 149 should be recorded as $D$. bellus Bukry and Percival-which is a smaller form, with more-tapered and lesscurved rays.

\section{Discoaster tristellifer Bukry}

(Plate 4, Figs. 1-6)

?Discoaster altus Muller, Martini, 1976, p. 420, pl. 12, figs. 17, 18 . Discoaster tristellifer Bukry, 1976, p. 499, pl. 1, figs. 1-17.

Remarks. This lower Pliocene warm-water species was not recorded from Leg 63 but was noted during a comparative study of DSDP tropical reference Site 83; the range of this species thus extends across the Pacific from DSDP Site 317 in the central Pacific and from DSDP Site 242 in the western Indian Ocean. The long rays and through-going central knob structure are very distinctive in wellpreserved material.

\section{Genus HELICOSPHAERA Kamptner, 1954 \\ Helicosphaera californiana $\mathbf{n} . \mathbf{s p}$.}

(Plate 4, Figs. 7-12)

Description. Helicosphaera californiana is a very small, very elongate $(\mathrm{L} / \mathrm{W} \geq 2)$ helicosphaerid with a long, narrow slit along the major axis of the central area. In cross-polarized light the rim is faint and narrow.

Remarks. Helicosphaera californiana is distinguished from similar $H$. carteri (Wallich) and $H$. scissura Miller by its much smaller size $(\sim 1: 2)$, narrower format in cross-polarized light, and great length and uniform width of the central slit.

Occurrence. Helicosphaera californiana is common in California Continental Borderland USGS dart core GSCD-125, which contains a lower middle Miocene assemblage of Zones CN4 or CN5. It does not occur in the assemblages recovered by Leg 63 .

Size. Maximum length: 6 to $7 \mu \mathrm{m}$ (holotype $7 \mu \mathrm{m}$ ).

Holotype. USNM 307315 (Plate 4, Figs. 9-11).

Isotype. USNM 307316 and 307317.

Type locality. California Continental Borderland USGS dart core GSCD-125 $\left(32^{\circ} 43.7^{\prime} \mathrm{N}, 119^{\circ} 20.5^{\prime} \mathrm{W}, 770 \mathrm{~m}\right)$.

Helicosphaera crouchii n. sp.

(Plate 4, Figs. 13-16; Plate 5, Figs. 1-4)

Description. This moderate to large helicosphaerid is elongate $(\mathrm{L} / \mathrm{W} \cong 2)$ and has two large equant, nearly as-long-as-wide pores that dominate the central area. The pores are separated by a long, narrow bar aligned with the minor axis. The rim cycle is moderately broad and smooth. In cross-polarized light the central area and bar are in optical continuity. A minor offset in the bar occurs on some specimens.

Remarks. Helicosphaera crouchii was noted as an early homeomorph for $\mathrm{H}$. sellii (Bukry and Bramlette) on the basis of dart core studies on the California Continental Borderland. A wide geographic extent for $H$. crouchii-as far as eastern Europe-was indicated through discussions with Maria Baldi Beke (personal communication, 1977). Its existence onshore in California was confirmed by Richard Z. Poore (personal communications, 1978, 1980) from Zone CN2 of the Sandholdt Member of the Monterey Formation in Reliz Canyon. Although many species of Helicosphaera have a central bar dividing two pores, only a few species are closely similar. $H$. crouchii is distinguished from $H$. sellii (Bukry and Bramlette) by larger size and proportionally larger pores, from $H$. transylvanica (manuscript name, N. Gheta, personal communication, 1980) by a longer bar and larger, more equant, unelongated pores, and from $H$. recta $\mathrm{Haq}$ by the more elongate, elliptic outline. Besides structural distinction, these four helicosphaerids have different stratigraphic ranges: $H$. recta (CP18 and CP19), $H$. transylvanica $(\mathrm{CN} 1), H$. crouchii $(\mathrm{CN} 2 / \mathrm{CN} 4), H$. sellii $(\mathrm{CN} 11 / \mathrm{CN} 14)$.

Occurrence. Helicosphaera crouchii occurs in Leg 63, Site 469, and is especially common in USGS dart core L2-78-SC-140 (from the California Continental Borderland area) in lower to lower middle Miocene assemblages of Zones CN2 to lower CN4.

Size. Maximum length: 10 to $15 \mu \mathrm{m}$ (holotype $15 \mu \mathrm{m}$ ).

Holotype. USNM 307318 (Plate 4, Figs. 13-14).

Isotypes. USNM 307319 to 307323.

Type locality. California Continental Borderland, USGS dart core L2-78-SC-140 $\left(32^{\circ} 04.6^{\prime} \mathrm{N}, 119^{\circ} 09.5^{\prime} \mathrm{W}, 800 \mathrm{~m}\right)$. 
Helicosphaera gertae n. sp.

(Plate 5, Figs. 5-13; Plate 6, Figs. 1-4)

Description. Helicosphaera gertae is a large species with a broad rim with a nearly oval outline. Rim elements are discernible by photomicroscopy. Some specimens show minor dovetailing of the margin at the narrower end of the oval. The central area is characterized by solid construction on either side of a median slit along the major axis. The length-to-width ratio of the rim periphery is quite low $(\mathrm{L} / \mathrm{W}=1.17-1.26)$.

Remarks. Helicosphaera gertae is distinguished from similar species such as $H$. compacta (Bramlette and Wilcoxon) by the long slit dividing the central area (see Bramlette and Wilcoxon, 1967) and from $H$. perchnielsenasae $(\mathrm{Haq})$ by the oval instead of subrectangular shape and by the long slit instead of two oblique grooves in the central area (see Haq, 1973).

Occurrence. Helicosphaera gertae is common in DSDP Sample $292-14-6,50-54 \mathrm{~cm}(129 \mathrm{~m})$, which is a clayey coccolith ooze of the lower Miocene Zone CN1. Site 292 is located on the Benham Rise in the western Philippine Sea, east of Luzon.

Size. Maximum length: 15 to $22 \mu \mathrm{m}$ (holotype $19 \mu \mathrm{m}$ ).

Holotype. USNM 307324 (Plate 5, Figs. 5-7).

Isotypes. USNM 307325 to 307329 .

Type locality. Western Philippine Sea, DSDP Sample 292-14-6, 50-54 cm (129 m).

\section{Helicosphaera scissura Miller}

(Plate 6, Figs. 5-7)

Helicosphaera scissura Miller, in press.

Remarks. Helicosphaera scissura is a narrow, moderate-sized species with a small median furrow. It is similar in appearance to $H$. carteri (Wallich) except for the furrow. H. scissura is prominent in several California Continental Borderland dart cores in Zone CN3. Miller (in press) records it as far north as Pt. Arena, California, in the same zone. It also occurs in DSDP Sample 469-37-2, 127-129 cm (343 $\mathrm{m})$ in Zone CN3.

Gartner (1977) has described a possible Pleistocene homeomorph of $H$. scissura as $H$. neogranulata Gartner. The repetition of certain structural plans in Helicosphaera at various times limits their independent biostratigraphic utility. Besides the shared structures of the $H$. scissura group, other repeated similar forms include Eocene $H$. seminulum Bramlette and Sullivan with Oligocene $H$. bramlettei (Müller) and $H$. wilcoxonii (Gartner), and also Miocene $H$. crouchii with Pliocene-Pleistocene $H$. sellii (Bukry and Bramlette). See Haq (1973) for discussions of structural variation in Helicosphaera.

\section{Helicosphaera vedderi $\mathrm{n} . \mathrm{sp}$.}

(Plate 6, Figs. 8-17)

Description. Helicosphaera vedderi is a small, thin helicosphaerid with a large elliptic central opening spanned by a narrow diagonal bar. The rim cycle is faint. The elongate central opening occupies about a third of the length of the minor axis. In cross-polarized light, the bar is bright at $45^{\circ}$ and dark at $0^{\circ}$ to the polarization axes. The bar is continuous within the inner margin and is angled at about $45^{\circ}$ to the major axis.

Remarks. Helicosphaera vedderi is distinguished from other helicosphaerid species with angled, central-area bars by its small size and proportionally larger opening relative to bar size. $H$. rhomba Bukry is larger and does not have margin-to-bar continuity in crosspolarized light. Other small helicosphaerids lack similar bar and central-area structures.

Occurrence. Helicosphaera vedderi occurs in the California Continental Borderland in USGS dart core S3-79-SC-289 from Garrett Ridge with lower or middle Miocene coccoliths of Zones $\mathrm{CN} 3$ and CN4. Its full range is yet to be determined.

Size. Maximum length 6 to $7 \mu \mathrm{m}$ (holotype $7 \mu \mathrm{m}$ ).

Holotype. USNM 307330 (Plate 6, Figs. 8-11).

Isotypes. USNM 307331 to 307333.

Type locality. California Continental Borderland, USGS dart core S3-79-SC-289 $\left(32^{\circ} 37.6^{\prime} \mathrm{N}, 119^{\circ} 33.7^{\prime} \mathrm{W}\right.$, depth $\left.285 \mathrm{~m}\right)$.

\section{Genus WISEORHABDUS n. gen.}

Description. Elongate, calcite rods are composed of several radial keels parallel to the major axis. The ends of the rods are blunt or pointed. The multiple keels may not be arrayed symmetrically (Wise and Constans, 1976).

Type species. Wiseorhabdus inversus (Bukry and Bramlette, emended Wise and Constans).

Remarks. Wiseorhabdus is distinguished from Lithraphidites and Triquetrorhabdulus by having more than four keels and by lacking exact radial symmetry about the major axis (Wise and Constans, 1976).

\section{Wiseorhabdus inversus (Bukry and Bramlette, emended} Wise and Constans) n. comb.

Triquetrorhabdulus inversus Bukry and Bramlette, 1969, p. 142, pl. 1, figs. 9-14.

Pseudotriquetrorhabdulus inversus (Bukry and Bramlette) emended, new combination, Wise and Constans, 1976, p. 154, pl. 4, figs. 1-9.

Remarks. Following Loeblich and Tappan (1970), the proposed transfer of Triquetrorhabdulus inversus to Pseudotriquetrorhabdulus is invalid by ICBN Art. 33, par. 4 (Lanjouw, et al., 1966), because the original publication-title and journal name-was never cited by Wise and Constans (1976). In order to validate their emended-species concept and to provide a briefer, unencumbered genus name, the species is, herein, transferred from Triquetrorhabdulus to Wiseorhabdus. Because Pseudotriquetrorhabdulus has never had a validated type species, this genus has not had formal status. Whereas it might possibly have been corrected (ICBN, Art. 63, Note; Lanjouw, 1966), this was not done, and Wiseorhabdus is now proposed as the new genus for the epithet inversus (as emended by Wise and Constans, 1976).

\section{SPECIES CITED OUTSIDE SYSTEMATIC PALEONTOLOGY}

Amaurolithus amplificus (Bukry and Percival, 1971) Gartner and Bukry, 1975

A. delicatus Gartner and Bukry, 1975

A. primus (Bukry and Percival, 1971) Gartner and Bukry, 1975

Arkhangelskiella cymbiformis Vekshina, 1959

Broinsonia parca (Stradner, 1963) Bukry, 1969

Calcidiscus leptoporus (Murray and Blackman, 1898) Loeblich and Tappan, 1978

C. macintyrei (Bukry and Bramlette, 1969) Loeblich and Tappan, 1978

Catinaster calyculus Martini and Bramlette, 1963

C. coalitus Martini and Bramlette, 1963

Ceratolithus acutus Gartner and Bukry, 1974

C. cristatus Kamptner, 1950

C. rugosus Bukry and Bramlette, 1968

Chiasmolithus consuetus (Bramlette and Sullivan, 1961) Hay and Mohler, 1967)

C. grandis (Bramlette and Riedel, 1954) Radomski, 1968

Coccolithus crassus Bramlette and Sullivan, 1961

C. formosus (Kamptner, 1963) Wise, 1973

C. miopelagicus Bukry, 1971

C. pelagicus (Wallich, 1877) Schiller, 1930

C. pliopelagicus Wise, 1973

Cribrosphaera ehrenbergii Arkhangelsky, 1912

Cyclicargolithus abisectus (Müller, 1970) Bukry, 1973

C. floridanus (Roth and Hay, 1967) Bukry, 1971

Dictyococcites bisectus (Hay, Mohler, and Wade, 1966) Bukry and Percival, 1971

Discoaster asymmetricus Gartner, 1969

D. aulakos Gartner, 1967

D. barbadiensis Tan, 1927

D. bellus Bukry and Percival, 1971

D. berggrenii Bukry, 1971

D. blackstockae Bukry, 1973

D. bollii Martini and Bramlette, 1963

D. braarudii Bukry, 1971

D. brouweri Tan, 1927

D. challengeri Bramlette and Riedel, 1954

D. decorus (Bukry, 1971) Bukry, 1973

D. deflandrei Bramlette and Riedel, 1954

D. exilis Martini and Bramlette, 1963

D. hamatus Martini and Bramlette, 1963

D. kugleri Martini and Bramlette, 1963

D. intercalaris Bukry, 1971 
D. loeblichii Bukry, 1971

D. mendomobensis Wise, 1973

D. moorei Bukry, 1971

D. multiradiatus Bramlette and Riedel, 1954

D. neohamatus Bukry and Bramlette, 1969

D. pansus (Bukry, 1971) Bukry, 1973

D. pentaradiatus Tan, 1927

D. prepentaradiatus Bukry and Percival, 1971

D. pseudovariabilis Martini and Worsley, 1971

D. quinqueramus Gartner, 1969

D. signus Bukry, 1971

D. surculus Martini and Bramlette, 1963

D. tamalis Kamptner, 1967

D. triradiatus Tan, 1927

D. variabilis Martini and Bramlette, 1963

Eiffellithus eximius (Stover, 1966) Perch-Nielsen, 1968

Emiliania annula (Cohen, 1964) Bukry, 1971

E. ovata Bukry, 1973

Gephyrocapsa caribbeanica Boudreaux and Hay, 1967

G. oceanica Kamptner, 1943

Hayaster perplexus (Bramlette and Riedel, 1954) Bukry, 1973

Helicosphaera ampliaperta Bramlette and Wilcoxon, 1967

H. carteri (Wallich, 1877) Kamptner, 1954

H. lophota (Bramlette and Sullivan, 1961) Jafar and Martini, 1975

H. sellii (Bukry and Bramlette, 1969) Jafar and Martini, 1975

H. seminulum Bramlette and Sullivan, 1961

Heliorthus distentus (Bramlette and Sullivan, 1961) Bukry, 1978

Marthasterites furcatus (Deflandre, 1954) Deflandre, 1959

Micula decussata Vekshina, 1959

Minylitha convallis Bukry, 1973

Prediscosphaera cretacea (Arkhangelsky, 1912) Gartner, 1968

Reticulofenestra pseudoumbilica (Gartner, 1967) Gartner, 1969

R. umbilica (Levin, 1965) Martini and Ritzkowski, 1968

Sphenolithus abies Deflandre, 1954

S. anarrhopus Bukry and Bramlette, 1969

S. heteromorphus Deflandre, 1954

S. neoabies Bukry and Bramlette, 1969

Tetralithus trifidus (Stradner, 1961) Bukry, 1973

Triquetrorhabdulus milowii Bukry, 1971

T. rugosus Bramlette and Wilcoxon, 1967

Watznaueria barnesae (Black, 1959) Perch-Nielsen, 1968

\section{ACKNOWLEDGMENT}

I thank Hans R. Thierstein, Scripps Institution of Oceanography, and Richard Z. Poore, U.S. Geological Survey, for their constructive reviews of this paper. John G. Vedder, U.S. Geological Survey, and James K. Crouch, U.S. Geological Survey (present address: Sohio Oil Co., San Francisco) provided excellent geologic background for coccolith occurrences in the California Continental Borderland. Dart core samples from the borderland used for references were supplied by John G. Vedder and George W. Moore, U.S. Geological Survey. Gerta Keller, Stanford University, provided material from DSDP 292 as part of a collaboration on a CENOP study. I thank Dorothy L. Blackstock, U.S. Geological Survey, for her valuable assistance in preparing the figures and typescript.

\section{REFERENCES}

Addicott, W. O., 1970. Latitudinal gradients in Tertiary molluscan faunas of the Pacific Coast. Palaeogeogr. Palaeoclimatol. Palaeoecol., 8:287-312.

Backman, J., 1978. Late Miocene-early Pliocene nannofossil biochronology and biogeography in the Vera Basin, SE Spain. Stockholm Contrib. Geol., 32(2):93-114.

Bizon, G., and Müller, C., 1978. Remarks on the determination of the Pliocene/Pleistocene boundary in the Mediterranean. In Hsü, K. J., Montadert, L., et al., Init. Repts. DSDP, 42, Pt. 1: Washington (U.S. Govt. Printing Office), 847-853.

Bramlette, M. N., and Wilcoxon, J. A., 1967. Middle Tertiary calcareous nannoplankton of the Cipero Section, Trinidad, W. I. Tulane Stud. Geol., 5:93-131.

Bukry, D., 1971a. Cenozoic calcareous nannofossils from the Pacific Ocean. San Diego Soc. Nat. History Trans., 16:303-327.

1971b. Discoaster evolutionary trends. Micropaleontology, 17:43-52. 1972a. Further comments on coccolith stratigraphy, Leg 12, Deep Sea Drilling Project. In Laughton, A. S., Berggren, W. A., et al., Init. Repts. DSDP, 12: Washington (U.S. Govt. Printing Office), 1071-1083.

1972b. Coccolith stratigraphy Leg 9, Deep Sea Drilling Project. In Hays, J. D., et al., Init. Repts, DSDP, 9: Washington (U.S. Govt. Printing Office), 817-832.

, 1973a. Low-latitude coccolith biostratigraphic zonation. In Edgar, N. T., Saunders, J. B., et al., Init. Repts. DSDP, 15: Washington (U.S. Govt. Printing Office), 685-703. , 1973b. Coccolith and silicoflagellate stratigraphy, Deep Sea Drilling Project Leg 18, eastern North Pacific. In Kulm, L. D., von Huene, R., et al., Init. Repts. DSDP, 18: Washington (U.S. Govt. Printing Office), 817-831.

1975. Coccolith and silicoflagellate stratigraphy, northwestern Pacific Ocean, Deep Sea Drilling Project Leg 32. In Larson, R. L., Moberly, R., et al., Init. Repts. DSDP, 32: Washington (U.S. Govt. Printing Office), 677-701.

1976. Coccolith stratigraphy of Manihiki Plateau, central Pacific, Deep Sea Drilling Project Site 317. In Schlanger, S. O., Jackson, E. D., et al., Init. Repts. DSDP, 33: Washington (U.S. Govt. Printing Office), 493-501.

1979. Coccolith and silicoflagellate stratigraphy, northern Mid-Atlantic Ridge and Reykjanes Ridge, Deep Sea Drilling Project Leg 49. In Luyendyk, B. P., Cann, J. R., et al., Init. Repts. DSDP, 49: Washington (U.S. Govt. Printing Office), 551-581. 1980. Coccolith stratigraphy, tropical eastern Pacific Ocean Deep Sea Drilling Project Leg 54. In Hekinian, R., Rosendahl, B. R., et al., Init. Repts. DSDP, 54: Washington (U.S. Govt. Printing Office), 535-544.

Bukry, D., and Bramlette, M. N., 1969. Some new and stratigraphically useful calcareous nannofossils of the Cenozoic. Tulane Stud. Geol. Paleontol., 7:131-142.

Bukry, D., and Kennedy, M. P., 1969. Cretaceous and Eocene coccoliths at San Diego, California. Calif. Div. Mines and Geol. Spec. Rep., 100:33-43.

Crouch, J. K., 1979. Neogene tectonic evolution of the California Continental Borderland and western Transverse Ranges. Bull. Geol. Soc. Am., Pt. 1, 90(4):338-345.

Crouch, J. K., and Bukry, D., 1979. Comparison of Miocene provincial foraminiferal stages to coccolith zones in the California Continental Borderland. Geology, 7:211-215.

Douglas, R. G., and Savin, S. M., 1973. Oxygen and carbon isotope analyses of Cretaceous and Tertiary Foraminifera from the central North Pacific. In Winterer, E. L., Ewing, J. I, et al., Init. Repts. DSDP, 17: Washington (U.S. Govt. Printing Office), 591-605.

Ellis, H. C., Lohman, W. H., and Wray, J. L., 1972. Upper Cenozoic calcareous nannofossils from the Gulf of Mexico (Deep Sea Drilling Project, Leg 1, Site 3). Colo. Sch. Mines Q., 67(3):1-103.

Fonseca, B., 1976. Coccolithus taganus, nouvelle espèce de coccolithophoridé du Miocène de Lisbonne. Bol. Soc. Geol. Portugal, 20:29-32.

Gartner, S., Jr., 1967. Calcareous nannofossils from Neogene of Trinidad, Jamaica, and Gulf of Mexico. Univ. Kansas Paleont. Contrib., Paper 29:1-7.

1969. Correlation of Neogene planktonic foraminifer and calcareous nannofossil zones. Trans. Gulf Coast Assoc. Geol., 19: 585-599.

1977. Calcareous nannofossil biostratigraphy and revised zonation of the Pleistocene. Mar. Micropaleontol., 2:1-25.

Haq, B. U., 1973. Evolutionary and trends in the Cenozoic coccolithophore genus Helicopontosphaera. Micropaleontology, 19:32-52.

Haq, B. U., Berggren, W. A., and Van Couvering, J. A., 1977. Corrected age of the Pliocene/Pleistocene boundary. Nature, 269: 483-488.

Haq, B. U., and Lohmann, G. P., 1976. Early Cenozoic calcareous nannoplankton biogeography of the Atlantic Ocean. Mar. Micropalentol., 1:119-194.

Hay, W. W., 1970. Calcareous nannofossils from cores recovered on Leg 4. In Bader, R. G., Gerard, R. D., et al., Init. Repts. DSDP, 4: Washington (U.S. Govt. Printing Office), 455-501.

Hay, W. W., and Beaudry, F. M., 1973. Calcareous nannofossilsLeg 15, Deep Sea Drilling Project. In Edgar, N. T., Saunders, J. B., et al., Init. Repts. DSDP, 15: Washington (U. S. Govt. Printing Office), 625-683. 
Hay, W. W., Mohler, H., and Wade, M. E., 1966. Calcareous nannofossils from Nal'chik (Northwest Caucasus). Eclogae Geol. Helv. 59:379-400.

Kamptner, E., 1967. Kalkflagellaten-Skelettreste aus Tiefseeschlamm des Südatlantischen Ozeans. Ann. Naturhist. Mus. Wien, 71: 117-198.

Lanjouw, J., et al., (Eds.), 1966. International Code of Botanical Nomenclature Adopted by the Tenth International Botanical Congress, Edinburgh, August 1964: Utrecht (International Bureau for Plant Taxonomy and Nomenclature).

Loeblich, A. R., Jr., and Tappan, H., 1970. Annotated index and bibliography of the calcareous nannoplankton V. Phycologia, 9: 157-174.

, 1978. The coccolithophorid genus Calcidiscus Kamptner and its synonyms. J. Paleontol., 52 (6):1390-1391.

Lynn, R. J., 1967. Seasonal variation of temperature and salinity at 10 meters in the California Current. California Cooperative Oceanic Fisheries Investigations Reports, 11:157-186.

Martini, E., 1971. Standard Tertiary and Quaternary calcareous nannoplankton zonation. Proc. 2nd. Planktonic Conf., 739-785.

,1976. Cretaceous to recent calcareous nannoplankton from the central Pacific Ocean (DSDP Leg 33). In Schlanger, S. O., Jackson, E. D., et al., Init. Repts. DSDP, 33: Washington (U.S. Govt. Printing Office), 383-423.

Martini, E., and Bramlette, M. N., 1963. Calcareous nannoplankton from the experimental Mohole drilling. J. Paleontol., 37:845-856.

McIntyre, A., Bé, A. W. H., and Roche, M. B., 1970. Modern Pacific Coccolithophorida: a paleontological thermometer. Trans. New York Acad. Sci., 32:720-731.

Miller, P. L., in press. Tertiary calcareous nannoplankton and benthic foraminifera biostratigraphy of the Point Arena area, California. Micropaleontology.

Milow, E. D., 1970. Tentative nannofossil zones and subzones and their radiometric age, northeast Pacific. In McManus, D. A.,
Burns, R. E., et al., Init. Repts. DSDP, 5: Washington (U.S. Govt. Printing Office), 8-10.

Müller, C., 1978. Neogene calcareous nannofossils from the Mediterranean-Leg 42A of the Deep Sea Drilling Project. In Hsü, K. J. Montadert, L., et al., Init. Repts. DSDP, 42, Pt. 1: Washington (U.S. Govt. Printing Office), 727-751.

Okada, H., and Bukry, D., 1980. Supplementary modification and introduction of code numbers to the low-latitude coccolith biostratigraphic zonation (Bukry, 1973; 1975). Mar. Micropaleontol. $5: 321-325$.

Okada, H., and Thierstein, H. R., 1979. Calcareous nannoplanktonLeg 43, Deep Sea Drilling Project. In Tucholke, B. E., Vogt, P. R., et al., Init. Repts. DSDP, 43: Washington (U.S. Govt. Printing Office), 507-573.

Perch-Nielsen, K., 1971. Elektronenmikroskopische Untersuchungen an Coccolithen und verwandten Formen aus dem Eozän von Dänemark. Biol. Skr. K. Dan. Vidensk. Selsk., 18:1-76.

Roth, P. H., and Berger, W. H., 1975. Distribution and dissolution of coccoliths in the south and central Pacific. Cushman Found. Foraminiferal Res. Spec. Publ., 13:87-113.

Schrader, H.-J., 1974. Revised diatom stratigraphy of the experimental Mohole drilling, Guadalupe site. Proc. Calif. Acad. Sci., 39:517-562.

Shafik, S. ,1975. Nannofossil biostratigraphy of the southwest Pacific Deep Sea Drilling Project, Leg 30. In Andrews, J. E., Packham, G., et al., Init. Repts. DSDP, 30: Washington (U.S. Govt. Printing Office), 549-598.

Wise, S. W., Jr., 1973. Calcareous nannofossils from cores recovered during Leg 18, Deep Sea Drilling Project: biostratigraphy and observations of diagenesis. In Kulm, L. D., von Huene, R., et al., Init. Repts. DSDP, 18: Washington (U.S. Govt. Printing Office), 569-615.

Wise, S. W., Jr., and Constans, R. E., 1976. Mid-Eocene planktonic correlations: northern Italy-Jamaica, W. I. Trans. Gulf Coast Assoc. Geol. Socs., 26:144-155. 

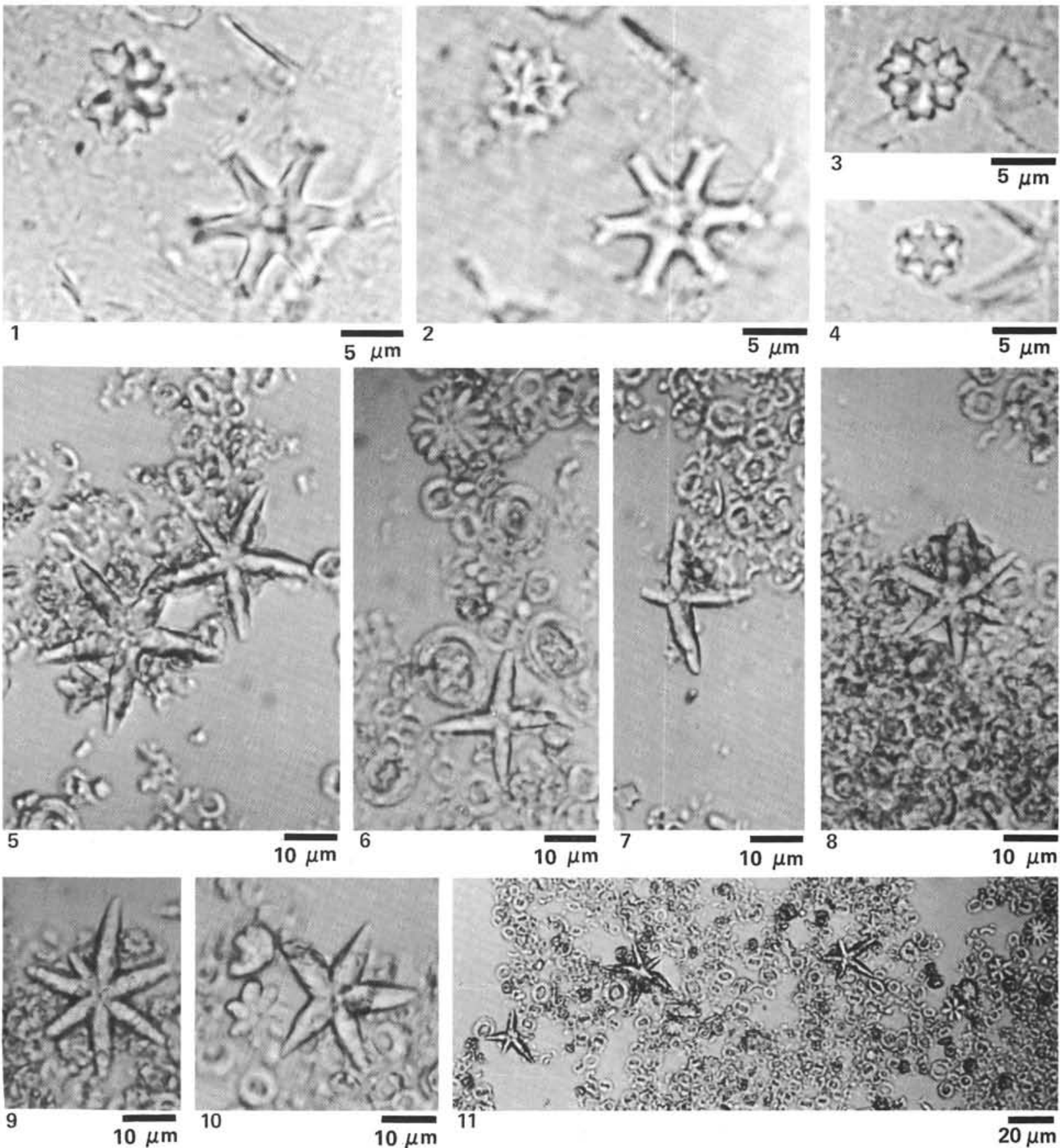

Plate 1. Cenozoic coccoliths from DSDP Legs 6 and 63. (Figs. 1-4 are magnified $\times 2050$; scale bar equals $5 \mu \mathrm{m}$; Figs. 5-10 are magnified $\times 800$; scale bar equals $10 \mu \mathrm{m}$. Fig. 11 is magnified $\times 350$; scale bar equals $20 \mu \mathrm{m}$.) $1-3$. Catinaster mexicanus Bukry. Sample $470 \mathrm{~A}-4-6,137 \mathrm{~cm}$. (1, 2) low and high focus with Discoaster variabilis Martini and Bramlette. 4. Catinaster sp., Sample 470A-4-6, $137 \mathrm{~cm}$. 5-11. Discoaster okadai $\mathrm{n}$. sp. Sample 47.2-8-6, 78-80 cm. (5) USNM 307288 and 307289, (6) USNM 307290 with Discoaster mohleri Bukry and Percival above, (7) USNM 307291, (8) USNM 307292, (9) USNM 307293, (10) USNM 307294, (11) USNM 307295 to USNM 307297, left to right. 

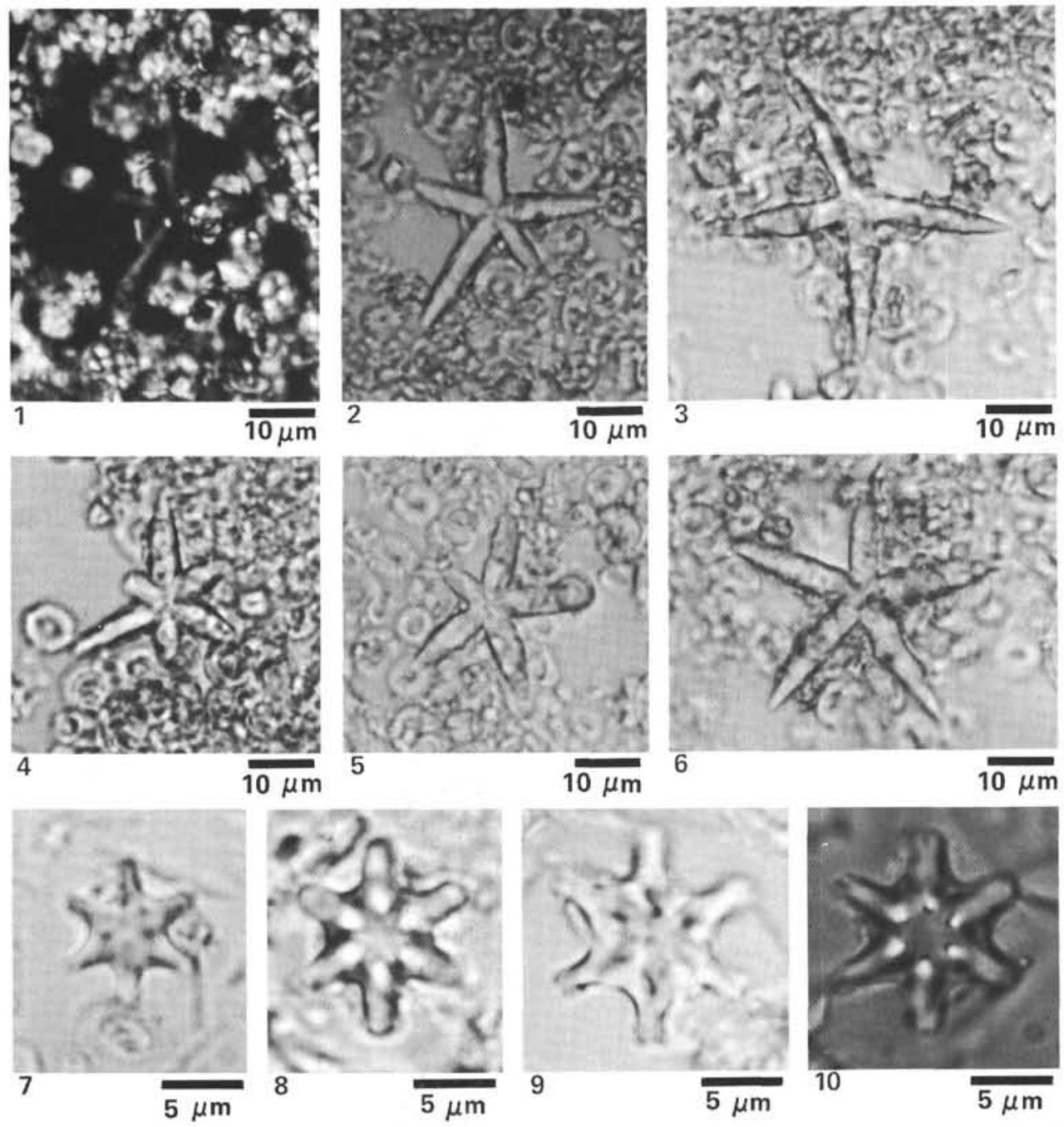

Plate 2. Cenozoic coccoliths from DSDP Legs 6 and 63. (Figs. 1-6 are magnified $\times 800$, scale bar equals $10 \mu \mathrm{m}$; Figs. 7-10 are magnified $\times 2050$, scale bar equals $5 \mu \mathrm{m}$.) 1-6. Discoaster okadai n. sp. DSDP Sample 47.2-8-6, 78-80 cm. $(1,2)$ cross-polarized light and bright field of same specimen, USNM 307298, (3) USNM 307299, (4) USNM 307300, (5) USNM 307301, (6) Holotype, USNM 307287. 7-10. Discoaster sanmiguelensis n. sp., (7) USNM 307303, USGS-S3-79-SC-259, (8) USNM 307304, DSDP Sample 468-7-3, 50-51 cm, (9) USNM 307305, DSDP Sample 468-2-3, 50-51 cm, (10) USNM 307306, USGS-S3-79-SC-259. 

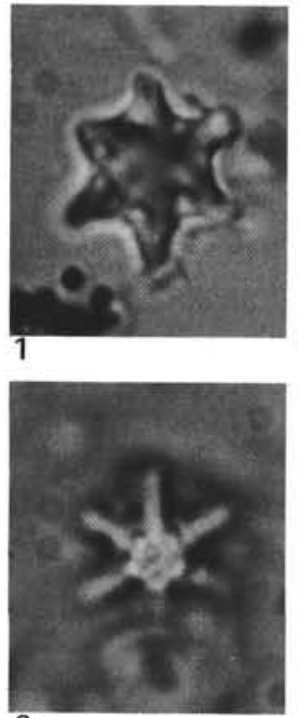

6

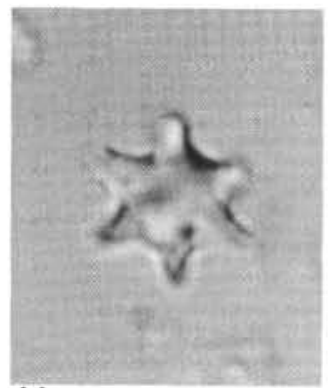

11

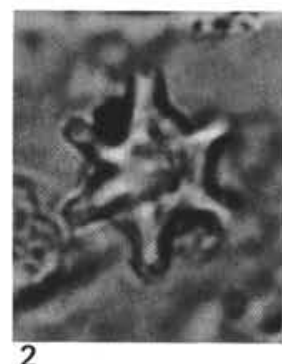

2

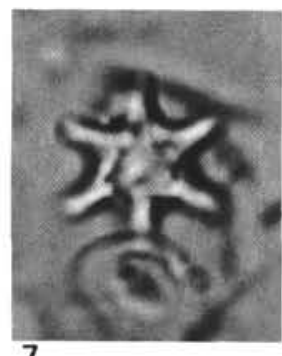

7
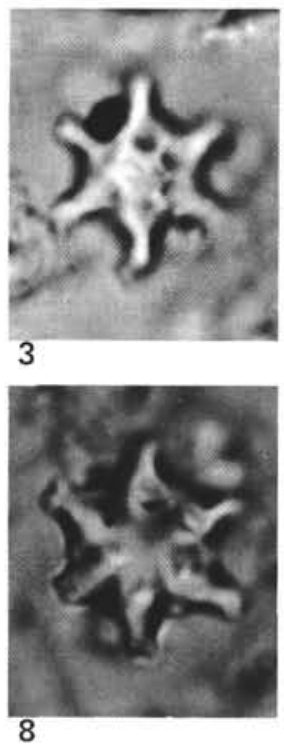

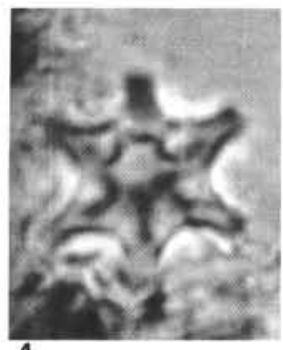

4

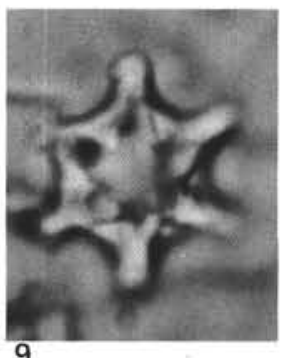

9

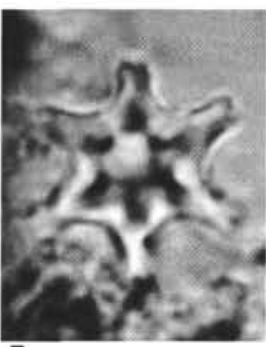

5

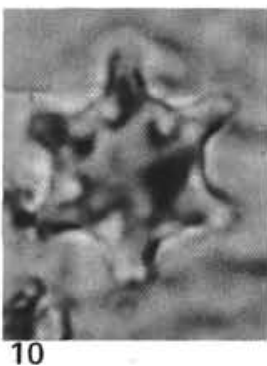

10
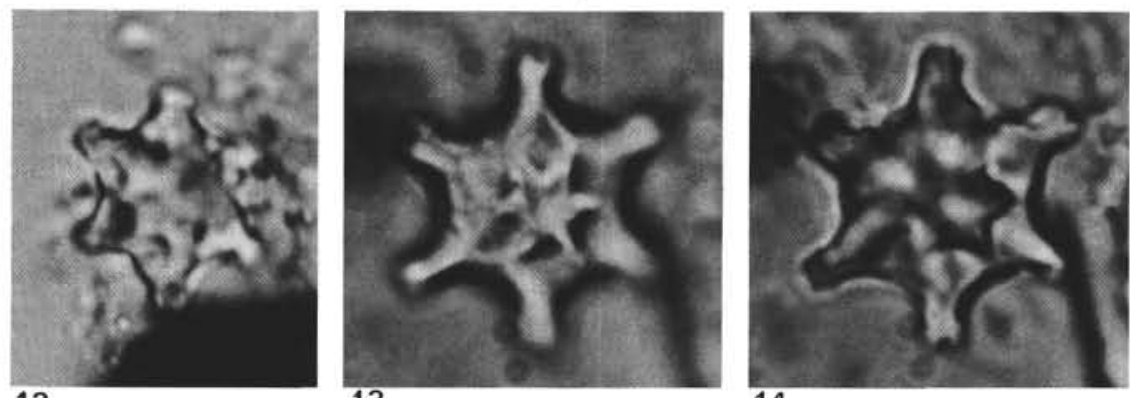

12

13

14

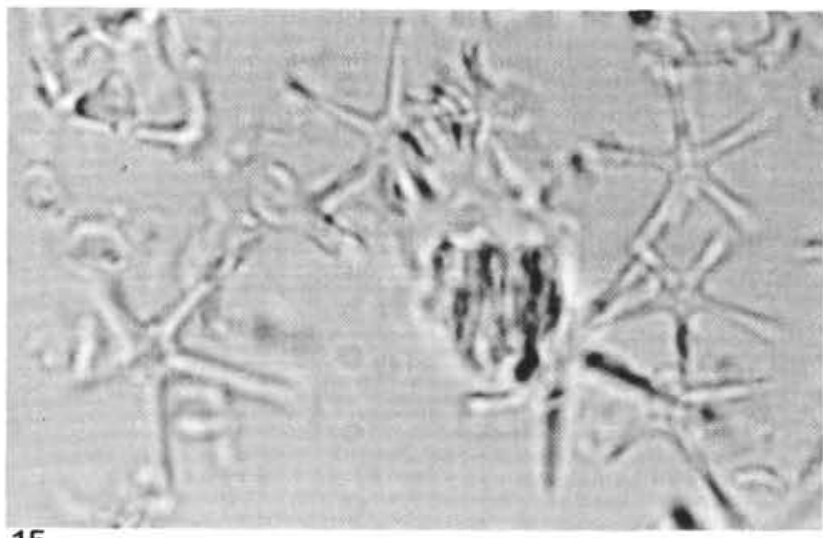

15

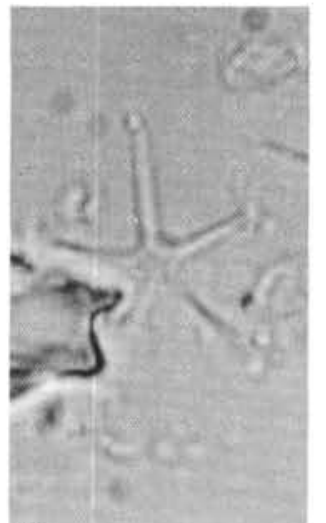

16

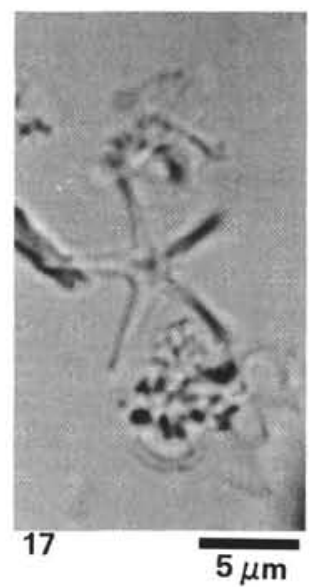

Plate 3. Cenozoic coccoliths from DSDP Leg 63 and USGS California Continental Borderland cores. (All figures are magnified $\times 2050$; scale bar equals $5 \mu \mathrm{m}$.) 1-14. Discoaster sanmiguelensis n. sp. DSDP Sample 468-9,CC, except Figs. 6, 7, and 11. (1) USNM 307307, (2, 3) Holotype, USNM 307302, low and high focus (LF and HF), (4, 5) USNM 307308, HF and LF, (6, 7) USNM 307309, HF and LF, USGS-S3-79-SC-259, (8) USNM 307310, $(9,10)$ USNM 307311, HF and LF, (11) USNM 307312, USGS-S3-79-SC-312, (12) USNM 307313, (13, 14) USNM 307314, HF and LF. 15-17. Discoaster tridenus Kamptner, emended DSDP Sample 470-5-2, 50-51 cm, (15) five specimens in one field of view, (16, 17) individuals showing central-area ornamentation. 

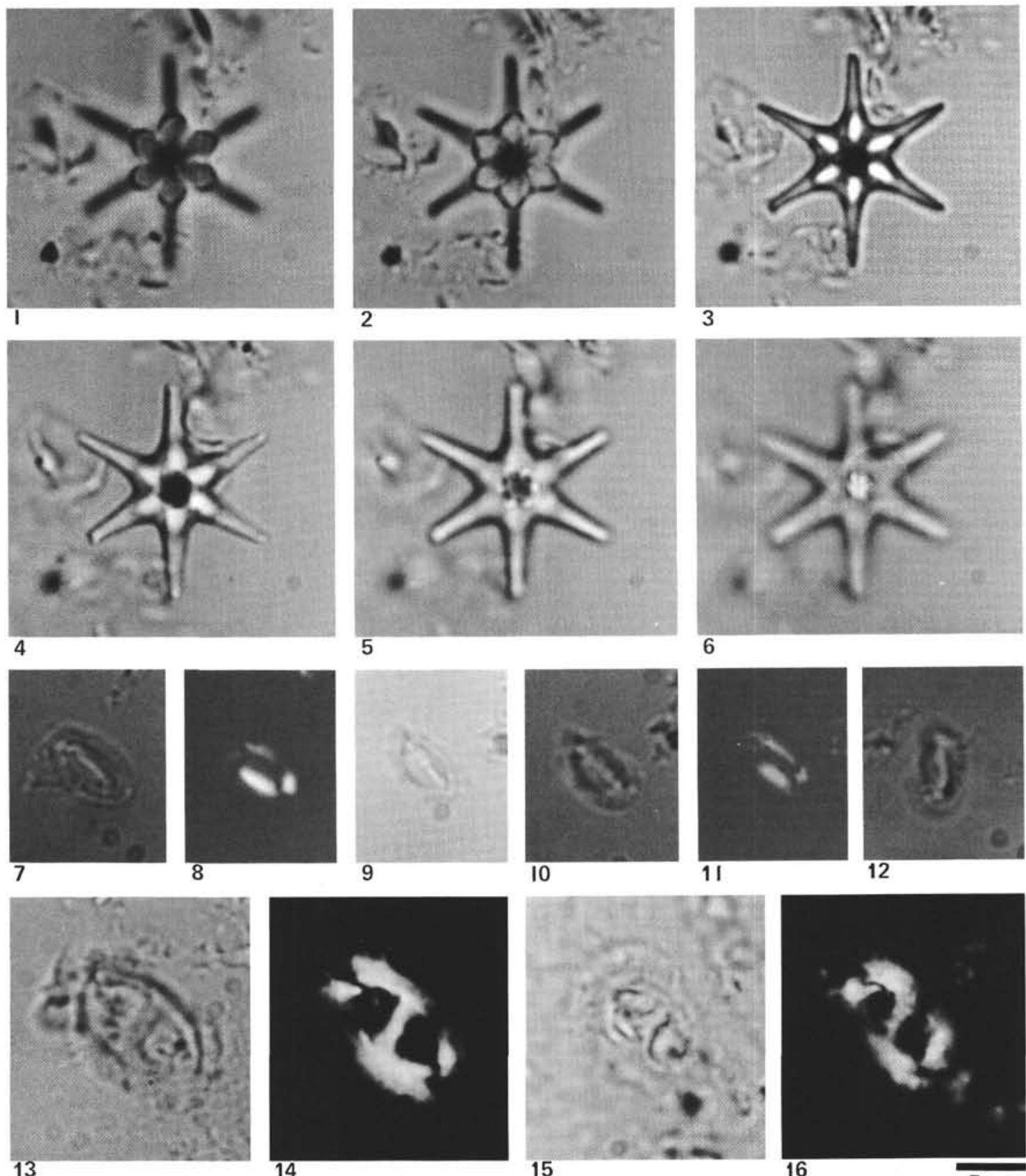

15

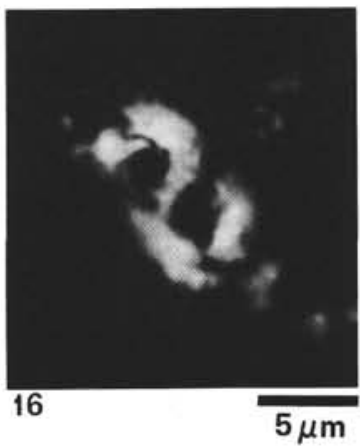

Plate 4. Cenozoic coccoliths from DSDP Leg 9 and USGS California Continental Borderland cores. (All figures are magnified $\times 2050$; scale bar equals $5 \mu \mathrm{m}$.) 1-6. Discoaster tristellifer Bukry (through-focal series showing disparate star-shaped knobs above and below plane of rays). DSDP Sample 83A-8-2, 101-102 cm. 7-12. Helicosphaera californiana n. sp. USGS-GSCD-125. (7, 8) USNM 307316, bright field and crosspolarized light (BF and XP), (9-11) Holotype, USNM 307315 (9. BF low focus; 10. BF high focus; 11. XP), (12) USNM 307317, BF. 13-16. Helicosphaera crouchii n. sp. USGS-L2-78-SC-140. (13, 14) Holotype, USNM 307318, BF and XP, (15, 16) USNM 307319, BF and XP. 

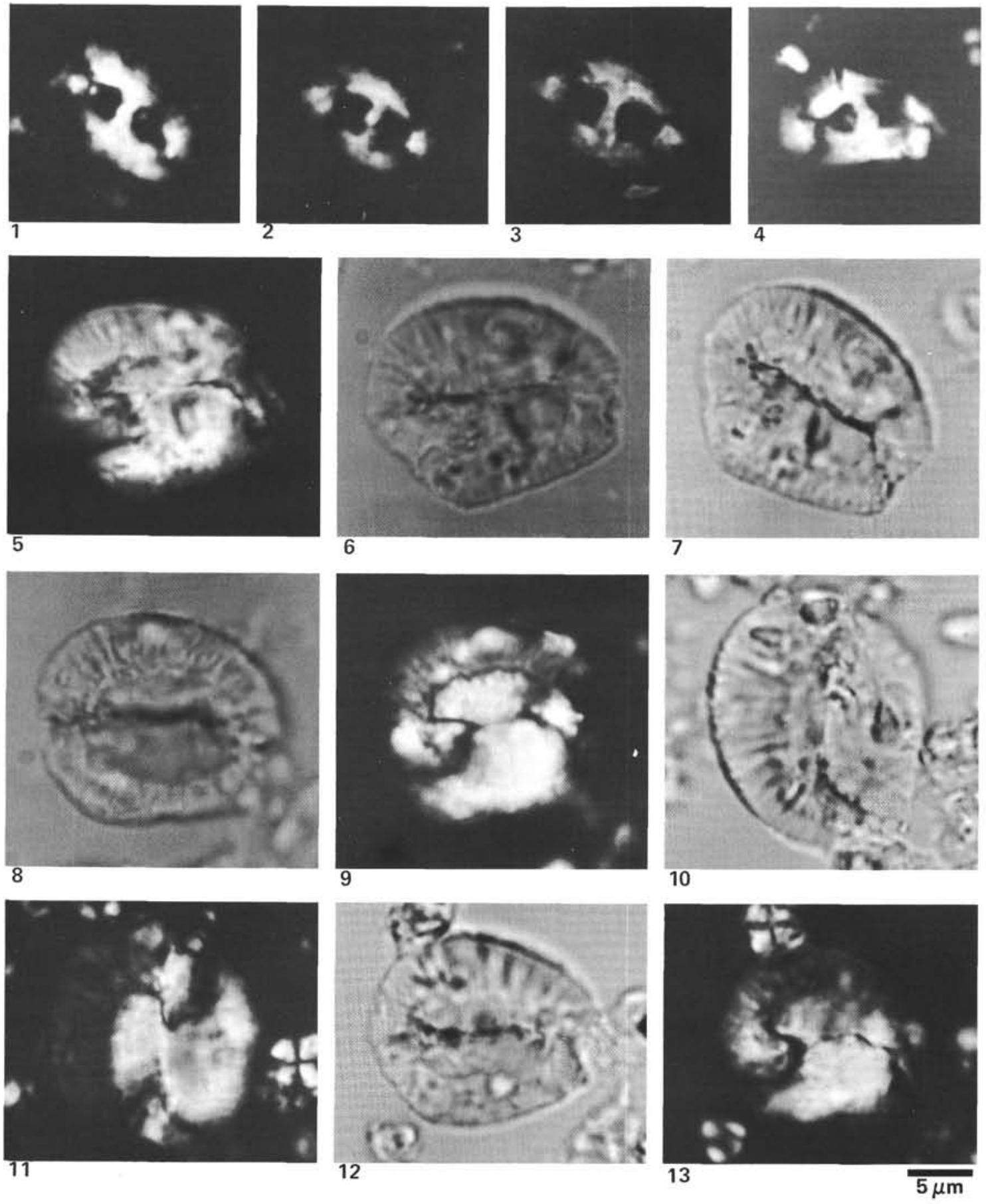

Plate 5. Cenozoic coccoliths from DSDP Leg 31 and USGS California Continental Borderland cores. (All figures are magnified $\times 2050$; scale bar equals $5 \mu \mathrm{m}$.) 1-4. Helicosphaera crouchii n. sp. USGS-L2-SC-140, except Fig. 4. (1) USNM 307320. (2) USNM 307321. (3) USNM 307322. (4) USNM 307323. DSDP Sample 469-35-1, $40 \mathrm{~cm}$. 5-13. Helicosphaera gertae n. sp. DSDP Sample 292-14-6, 50-54 cm. (5-7) Holotype, USNM 307324, XP, BF high focus, and BF low focus, $(8,9)$ USNM 307325, BF and XP, $(10,11)$ USNM 307326, BF and XP, (12, 13) USNM $307327, \mathrm{BF}$ and $\mathrm{XP}$. 


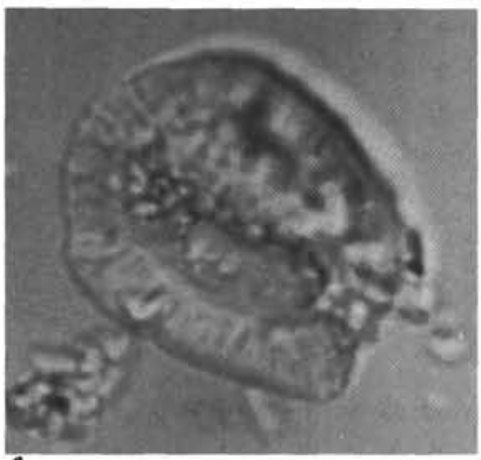
1

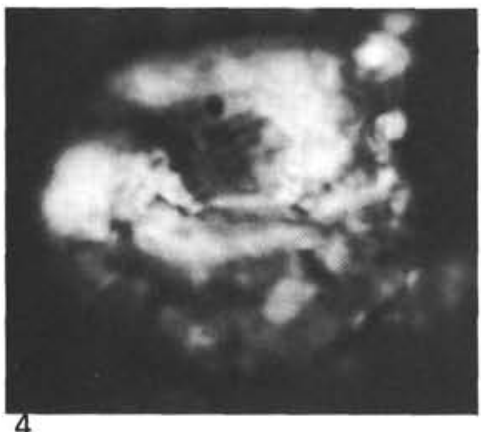
4

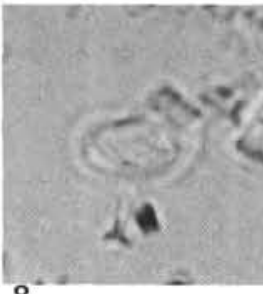

8

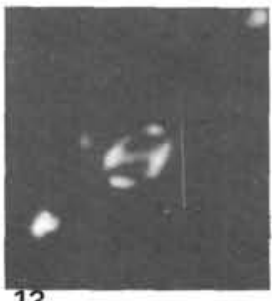

13

9

14

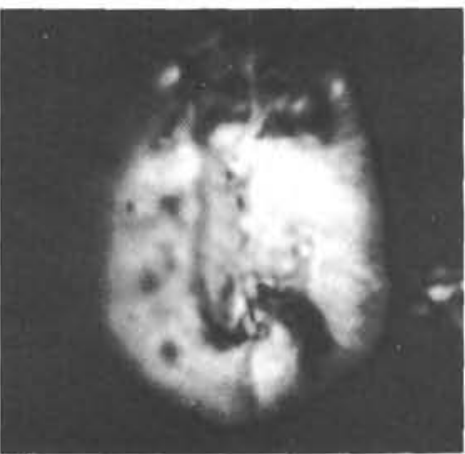

2

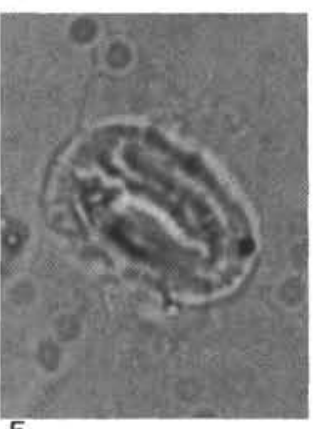

5
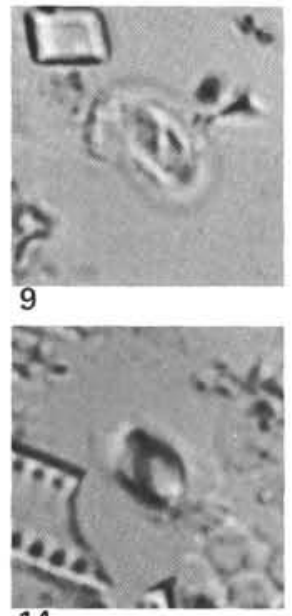

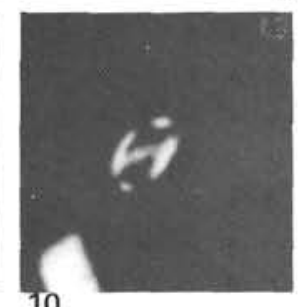

10

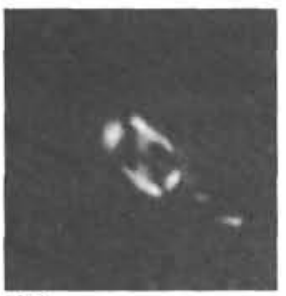

15

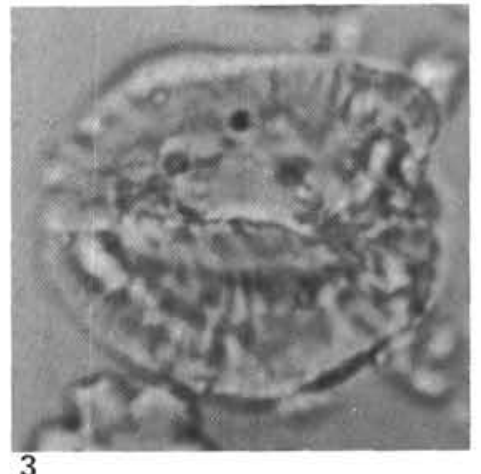

3

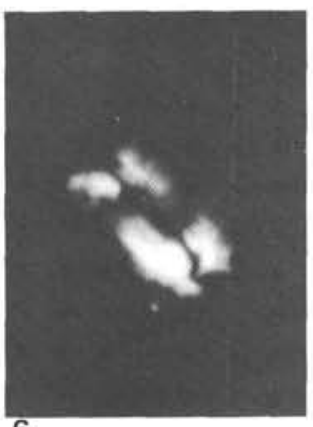

6

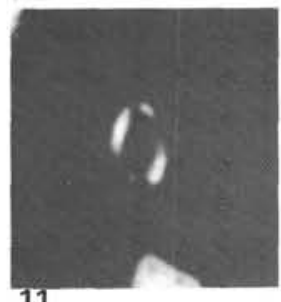

11
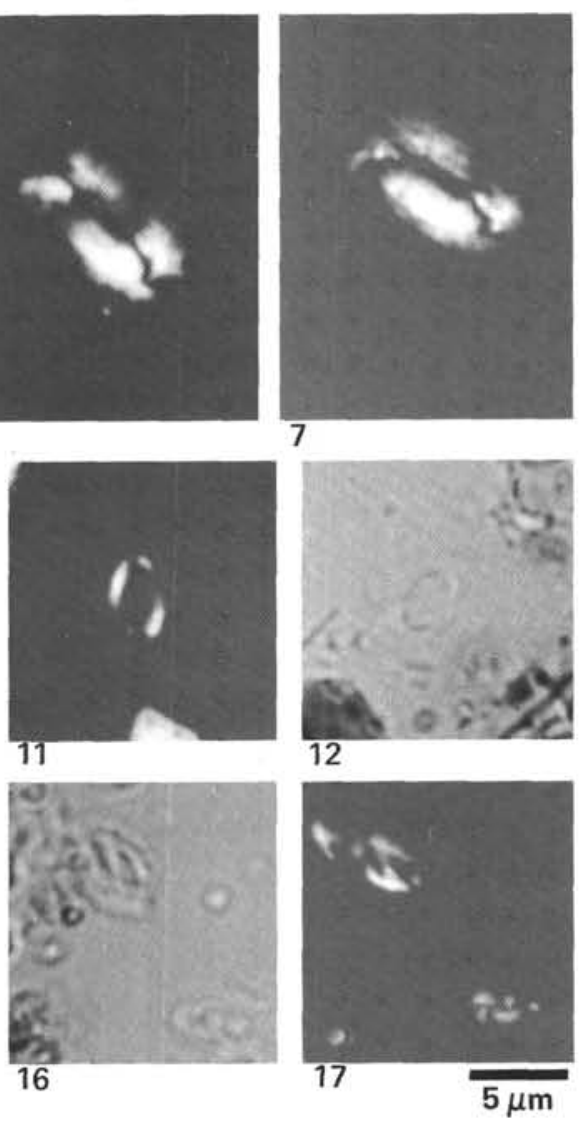

Plate 6. Cenozoic coccoliths from DSDP Legs 31 and 63 and USGS California Continental Borderland cores. (All figures are magnified $\times 2050$; scale bar equals $5 \mu \mathrm{m}$.) 1-4. Helicosphaera gertae n. sp. DSDP Sample 292-14-6, 50-54 cm. $(1,2)$ USNM 307328, BF and XP, $(3,4)$ USNM $307329, \mathrm{BF}$ and XP. 5-7. Helicosphaera scissura Miller. All figures of one specimen from DSDP Sample 469-37-2, 127-129 cm. (5) BF. (6) XP, $45^{\circ}$. (7) XP, $>45^{\circ}$ gives apparent slit elongation. 8-17. Helicosphaera vedderi $\mathrm{n}$. sp. USGS-S3-79-SC-289. (8-11) Holotype, USNM 307330 (8. $\mathrm{BF}$, low focus; 9 . BF, high focus; 10 . XP, $45^{\circ} ; 11$. XP, $\left.0^{\circ}\right),(12,13)$ USNM 307331 , BF and XP, $(14,15)$ USNM 307332 , phase contrast and XP. $(16,17)$ USNM 307333, BF and XP, at upper left; minute specimen at lower right is likely Crenalithus taganus (Fonseca). 